\title{
AS RELAÇÕES JURÍDICAS ADMINISTRATIVAS DE PRESTAÇÃO DE CUIDADOS DE SAÚDE*
}

\author{
JOSÉ MANUEL SÉRVULO CORREIA**
}

RESUMO: O presente texto analisa o direito à saúde sob a perspectiva da relação dos indivíduos com a Administração. Primeiramente discorre sobre a relação jurídica administrativa em geral e no que tange aos cuidados de saúde. Em seguida, trata dos sujeitos da relação: a Administração e os indivíduos utentes e beneficiários. É então abordado o conteúdo da relação, especialmente os direitos dos utentes e os poderes da Administração. Por fim, apresenta linhas gerais da forma como a relação se institui, se desenvolve e se extingue.

PALAVRAS-CHAVE: Administração. Direito à saúde. Usuários.

ABSTRACT: The present text analyses the right to health under the perspective of the relationship between individuals and the Administration. Firstly it discusses the administrative legal relationship in general and in what it concerns healthcare. In the follow-up, it deals with the relationship subjects: the Administration and the users and beneficiaries. It then approaches the relationship's content, especially the users' rights and the Administration's powers. Lastly, it presents generally the way by which the relationship is established, develops itself and is extinguished.

KEYWORDS: Administration. Right to health. Users.

Artigo recebido em 11.03.2009 e aprovado para publicação pelo Conselho Editorial em 23.06.2009.

* De uma colectânea intitulada Direito da Saúde e Bioética, editada em 1996 pela Associação Académica da Faculdade de Direito da Universidade de Lisboa, consta um texto de minha autoria, intitulado As Relações Jurídicas de Prestação de Cuidados pelas Unidades de Saúde do Serviço Nacional de Saúde. Tal como o presente, aquele escrito nasceu de uma minha intervenção num curso de pós-graduação. Em 1993 (ano em que as sessões tiveram lugar), esta designação não fora ainda institucionalizada. Mas foi essa na realidade a natureza do Curso, organizado conjuntamente pela Faculdade de Direito de Lisboa e pela Escola Nacional de Saúde Pública.

Doze anos decorridos sobre aquela publicação e quinze sobre a lição a que ela dava forma editorial, constituiu um exercício interessante a revisitação daquele texto no âmbito da preparação de uma nova prelecção do mesmo tipo. Tratava-se, naturalmente, de tomar em conta a evolução legislativa. O aspecto mais desafiante do exercício não estava porém aí, mas no reajustamento (que não na substituição) do enquadramento teórico em face da evolução doutrinária e do maior rigor analítico do meu próprio olhar de juspublicista, sob o peso benéfico de mais de uma década de estudo exigente. Foi um percurso feito, no tempo de vida, a par do de Paulo de Pitta e Cunha, uma vez que somos colegas de curso de licenciatura e que poucos meses nos separam na idade. É com muito gosto que destino este texto à participação na homenagem da comunidade académica a este Condiscípulo e Amigo.

Agradeço à Assistente da Faculdade de Direito de Lisboa Mestra Cláudia Monge a proficiente (e complexa) repertoriação da legislação em vigor.

** Professor catedrático jubilado da Faculdade de Direito da Universidade de Lisboa 
SUMÁRIO: 1. A relação jurídica administrativa como figura dogmática estruturante do direito administrativo de prestação; 2. Os sujeitos; 3 . O conteúdo; 4. Início, desenvolvimento e extinção.

SUMMARY: 1 . The administrative legal relationship as a structuring dogmatic figure of the provider administrative law; 2. The subjects; 3. The content; 4. Establishment, development and extinguishment.

\section{A RELAÇÃO JURÍDICA COMO FIGURA DOGMÁTICA ESTRUTURANTE DO DIREITO ADMINISTRATIVO DE PRESTAÇÃO.}

\section{A relação jurídica administrativa.}

1. Encontram-se postas de lado há muito tempo as tentativas de utilizar a figura da relação jurídica como matriz de concatenação da Teoria Geral do Direito Administrativo. Entre nós, MARCELLO CAETANO, que adoptara esse método de exposição desde o Tratado Elementar de Direito Administrativo, em 1943, afastou-o a partir da 8. ${ }^{a}$ edição do Manual, em 1968, por entender que ele conduzia à cisão artificial de institutos relativamente aos quais se justificava um exame integrado ${ }^{1}$.

Nas últimas décadas, notou-se, designadamente em Portugal, uma renovação do esforço doutrinário para explorar as possibilidades de converter a relação jurídica em conceito central do Direito Administrativo. Procurou-se particularmente preencher desse modo o relativo vazio decorrente da recondução do instituto do acto administrativo ao papel de uma entre várias formas de conduta típica da Administração, em vez de núcleo irradiante único ou largamente predominante na construção da Teoria Geral do Direito Administrativo². Este esforço não foi inútil, mas os seus resultados positivos não significam que se tenham concretizado todas as expectativas que inicialmente o rodearam.

Em primeiro lugar, merece ser sublinhado que, na própria Teoria do Direito Civil, de onde é originária, a figura da relação jurídica tem vindo a ser reduzida a uma escala que já não corresponde ao papel de eixo dogmático central. Como escreve MENEZES CORDEIRO, «Convém focar que a relação jurídica é apenas uma das várias situações jurídicas possíveis. Pretender reduzir toda a realidade a relações jurídicas, para além das cesuras metodológicas, técnicas e significativo-ideológicas..., é irrealista e provoca distorções contínuas». O papel primordial cabe hoje - segundo aquele Autor - às situações jurídicas, qualquer das quais constitui o culminar de todo o processo de realização do direito, integrando a localização das fontes, a interpretação e a aplicação ${ }^{3}$.

Em segundo lugar - e revertendo agora para o Direito Administrativo - não parece aceitável aquela posição doutrinária que encara a relação jurídica como a nova determinação teorético-fundamental do posicionamento recíproco entre Estado e cidadão, construindo-a sobre o plano de um ordenamento paritário. Pensar assim significa

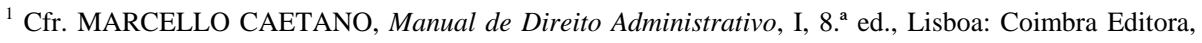
1968, p. 77.

${ }^{2}$ Cfr. VASCO PEREIRA DA SILVA, Em Busca do Acto Administrativo Perdido, Coimbra: Almedina, 1996, p. 149 s.

${ }^{3}$ Cfr. MENEZES CORDEIRO, Tratado de Direito Civil Português, I, Coimbra: Almedina, 1999, p. 99 e 102. 
esquecer que os próprios direitos subjectivos públicos são em geral um fruto da criação colectiva no quadro jurídico proporcionado pelo Estado e que este é detentor de específicos poderes de autoridade indispensáveis à realização das necessidades colectivas ${ }^{4}$.

E convém, em terceiro lugar, ter presente que, em abstracto, a figura da relação jurídica administrativa pouco mais significa que um envólucro vazio. Sabemos que confere unidade a um intercâmbio dinâmico entre Administração e particulares, que desenha acções e reacções de agentes num quadro de conexões, muitas vezes temporalmente alongado, em cujo decurso se geram situações subjectivas individualizadas passivas e activas. Mas a mais-valia que desta imagem se retira para a edificação do status do particular é reduzida. A figura apenas ganha densidade à medida que se concretizam as possibilidades e necessidades de conformação de situações jurídicas subjectivas específicas enquadradas pelas mais diversas normas jurídicas ${ }^{5}$.

Em suma, mais do que analisar em abstracto a figura da relação jurídica administrativa, importa olhar segundo os casos a uma multiplicidade de relações jurídicas administrativas, muito diversamente reguladas e preenchidas. A importância dogmática do modelo abstracto e vazio torna-se assim relativa. O interesse da figura avulta, em contrapartida, no âmbito de múltiplos Direitos Administrativos especiais ${ }^{6}$. Eis, desde logo, a razão pela qual faz sentido o seu emprego para o enquadramento jurídico das prestações administrativas de cuidados de saúde.

2. Uma coisa é, pois, a utilização da técnica da relação jurídica como matriz de organização e exposição do conjunto dos conceitos e dos institutos basilares do Direito Administrativo e outra, assaz diferente e mais profícua, a do emprego da relação jurídica como meio analítico da dinâmica de produção de efeitos jurídico-administrativos entre a Administração e os particulares no âmbito de regimes de objecto delimitado. Basta, por exemplo, notar que ACHTERBERG, um dos grandes defensores, em tempos recentes, do papel principal da ideia de relação jurídica num programa de redireccionamento dogmático da Ciência do Direito Administrativo, não se serviu dela como base sistémica do seu manual ${ }^{7}$.

No plano axiológico, o emprego da relação jurídica administrativa como instrumento da dogmática jurídica administrativa serve simultaneamente de veículo a um valor jurídico material de primeiro plano: não (como se observou já) o do nivelamento das capacidades jurídicas dos sujeitos de direito administrativo e particulares, mas o do respeito pelos destinatários da actividade administrativa como portadores de direito e interesses legalmente protegidos em face da Administração, isto é, como pessoas que não poderão ser olhadas como mero objecto de actos de poder ${ }^{8}$.

${ }^{4}$ Cfr. HOFFMANN-RIEM/SCHMIDT-ASSMANN/VOSSKUHLE, Grundlagen des Verwaltungsrechts, I, München: Beck, 2006, p. 455 e 456.

${ }^{5}$ Cfr. HOFFMANN-RIEM/SCHMIDT-ASSMANN/VOSSKUHLE, Grundlagen des Verwaltungsrechts, I, p. 455.

${ }^{6}$ MAURER, Allgemeines Verwaltungsrecht, 16a ed., München : Beck, 2006, p. 179.

${ }^{7}$ Cfr. ACHTERBERG, Allgemeines Verwaltungsrecht, $2^{\mathrm{a}}$ ed., Heidelberg: C.F. Müller, 1986. Após uma introdução, o manual de ACHTERBERG divide-se em três partes, respectivamente sobre os fundamentos de direito constitucional, a Administração enquanto organização e a administração enquanto função.

${ }^{8} \mathrm{O}$ emprego do conceito de relação jurídica não é apenas útil no domínio das posições recíprocas entre Administração e administrados: ele presta também um importante contributo para a clarificação dos modos 
3. Dentro dos limites enunciados, a figura da relação jurídica administrativa possui utilidade dogmática, permitindo simplificar inúmeras conjunturas de exercício da função administrativa, concentrando-as sob a estruturação de certos elementos. Ao contrário da dogmática do acto administrativo, o emprego da figura da relação não se concentra na decisão, mas no posicionamento recíproco de intervenientes na vida jurídica administrativa ligados uns aos outros por pontos de conexão.

Se bem que a relação jurídica se não tenha revelado como novo «ponto de Arquimedes» da sistemática jurídica administrativa, reina consenso sobre a sua utilidade quanto a uma melhor compreensão do sistema de actuação administrativa na sua vertente «comunicativa», ou seja, no tocante à articulação com a sociedade através de uma racionalidade discursiva ${ }^{9}$. A utilização da relação jurídica enquanto instituto de direito administrativo complementa a teoria das formas típicas de conduta administrativa graças ao simultâneo desempenho de uma função heurística, de uma função estruturante e de uma função dogmática.

A função heurística significa a utilidade do modelo relacional para a melhor compreensão dos meios próprios de comunicação entre Administração e particular. A visão relacional facilita uma percepção integrada de uma situação real da vida graças à sua redução a um esquema de situações subjectivas activas e passivas cujas correspondências e conexões assim se clarificam.

A função estruturante prende-se com a classificação ordenadora das diferentes relações jurídicas em função do seu objecto e dos subsistemas normativos do Direito Administrativo em que elas se alojam. Um tal esforço ajuda a determinar os núcleos preceptivos aplicáveis. Mas não se queda por aí, uma vez que são frequentes as sobreposições de áreas ou as dinâmicas interactivas com um consequente alargamento do quadro normativo.

A função dogmática respeita às consequências normativas que especificamente decorrem da verificação de uma relação jurídica administrativa. A localização da relação numa área de regime assaz específico tem consequências a nível de interpretação e de preenchimento de lacunas sob uma perspectiva de encadeamento funcional e de convocação conjugada de preceitos em abstracto não relacionados. Em termos de redução da complexidade, o papel dogmático da relação jurídica administrativa acentua-se quando esta realça a unidade funcional numa situação caracterizada pela multipolaridade ${ }^{10}$.

4. Falta no entanto precisar ainda aquilo que se deverá entender por relação jurídica administrativa.

As definições de relação jurídica são inúmeras. Interessa-nos naturalmente, num estudo com o objecto do presente, ater-nos a sentidos usados pela doutrina administrativista.

de relacionamento entre pessoas colectivas que integram a Administração e, eventualmente, até no seio de uma mesma pessoa colectiva pública. Cfr. ACHTERGERG, Allgemeines Verwaltungsrecht, cit., p. 382-391; Die Rechtsordnung als Rechtsverhältnisordnung, Berlin: Duncker \& Humblot, 1982, p. 36-43.

${ }^{9}$ Cfr. SCHMIDT-ASSMANN, Das Allgemeine Verwaltungsrecht als Ordnungsidee, Berlin/Heidelberg: Springer, 1998, p. 41; HOFFMANN-RIEM / SCHMIDT-ASSMANN / VOSSKUHLE, Grundlagen des Verwaltungsrecht, II, München: Beck, 2008, p. 180.

${ }^{10}$ Cfr. SCHMIDT-ASSMANN, Das Allgemeine Verwaltungsrecht als Ordnungsidee, cit., p. 255-258. 
Uma noção ainda bastante influenciada pela Teoria Pura do Direito é a de ACHTERBERG, que vê na relação jurídica uma conexão conformada pelo Direito entre dois ou mais sujeitos. Este autor entende por sujeitos os «pólos finais de imputação» (Zurechnungsendpunkten), ou seja, aqueles elementos estruturais do ordenamento a quem são assacados efeitos de direito ${ }^{11}$. Outros autores mais propensos a valorizar as interdependências entre o jurídico e o ambiente social ${ }^{12}$ apontam como traço essencial a existência de uma relação social regida pelo Direito. É o caso da definição de relação jurídica proposta por WOLFF/BACHOF/STOBER: a concretização de uma situação jurídica através da aplicação de momentos do Tatbestand de uma norma jurídica a uma relação social regulada por aquela norma e estabelecida entre sujeitos individualizados ${ }^{13}$.

No tocante à relação jurídica administrativa, cremos que ela poderá ser definida como um sistema complexo de situações jurídicas activas e passivas interligadas, regidas pelo Direito Administrativo e tituladas por entidades incumbidas do exercício de uma actividade específica da função administrativa e por particulares ou apenas por diversos pólos finais de imputação pertencentes à própria Administração ${ }^{14}$.

A relação jurídica administrativa pode compor-se de um só direito e da obrigação correspondente. Todavia, em geral o acto ou a situação de facto que surgem na base de uma de tais relações engendram desde logo diversos direitos e obrigações. E, à medida que a relação jurídica administrativa se prolonga no tempo, novos direitos e obrigações (ou outras situações jurídicas activas e passivas) vêm juntar-se aos primeiros ${ }^{15}$. Como veremos, é precisamente o que sucede com as relações jurídicas administrativas de prestação de cuidados de saúde.

\section{A relação jurídica e o Direito Administrativo de prestação.}

5. Como é bem sabido, o Estado Social desenvolveu, a par de uma orgânica e de um âmbito clássicos de actuação administrativa, assentes sobretudo no estabelecimento de limitações impostas pelo bem comum sobre a liberdade e a propriedade dos cidadãos, uma outra área, vocacionada para a realização de prestações destinadas a satisfazer direitos de ordem social, económica e cultural. Ao lado de um status negativus, constituído por limites à intervenção pública de carácter ablativo, a esfera de cidadania enriqueceu-se com a inclusão de um status positivus, formado por pretensões tendo por objecto uma actividade prestadora da Administração. Embora não existam limites estanques com os modos e finalidades tradicionais de actuação e organização, fala-se aí, com uma inevitável margem de imprecisão científica, de administração prestadora ou de prestação (Leistungsverwaltung) ${ }^{16}$.

\footnotetext{
${ }^{11}$ Cfr. ACHTERGERG, Allgemeines Verwaltungsrecht, p. 372-374.

12 Cfr. MARCELO REBELO DE SOUSA, A Lei no Estado Contemporâneo, in: Legislação, n. ${ }^{\circ}$ 11, Outubro-Dezembro de 1994, p. 12.

${ }^{13}$ Cfr. WOLFF/BACHOF/STOBER, Verwaltungsrecht, I, $11^{\text {a }}$ ed., München: Beck, 1999, p. 484-485.

14 Parcialmente neste sentido, ÖHLINGER, Rechtsverhältnisse in der Leistungsverwaltung, in: Veröffentlichungen der Vereinigung der Deutschen Staatsrechtslehrer, n. ${ }^{\circ} 45$ (1987), p. 189.

${ }^{15}$ Cfr. GRISEL, Traité de Droit Administratif, II, Neuchatel : Ides et Calendes, p. 584 ; RASCHAUER, Allgemeines Verwaltungsrecht, Wien/New York : Springer, 1998, p. 600 s.

${ }^{16} \mathrm{Cfr}$., a título de exemplo, DETTERBECK, Allgemeines Verwaltungsrecht mit Verwaltungsprozessrecht, $6^{\text {a }}$ ed., München : BECK, 2008, p. 4 ; FABER, Verwaltungsrecht, 4. ${ }^{\text {a }}$ ed., Tübingen : Mohr, 1995, p. 30-35.
} 
No plano funcional, a administração prestadora caracteriza-se pela relevância no seu seio de outras formas de actividade a par do clássico acto administrativo. São neste domínio particularmente numerosos os actos ou operações materiais (Verwaltungsrealakten). Estes consistem na prestação de serviços ou de coisas: são condutas unilaterais da Administração que se dirigem apenas à produção de efeitos de facto e não de efeitos de direito. Os actos materiais não constituem fonte de regulação jurídica, embora a sua produção seja, ela sim, disciplinada pelo Direito Administrativo $^{17}$.

As primeiras leis de procedimento administrativo ignoraram a figura do acto material de administração. Mas o desenvolvimento dos institutos e das formas da administração de prestação não permitiu que uma realidade de peso evidente no seio das condutas administrativas continuasse desprovida de uma forma típica. Encontramos uma satisfação, ainda que imperfeita, dessa necessidade no art. $2^{\circ}$ do Código do Procedimento Administrativo, cujo $\mathrm{n}^{0} 5$ determina que os princípios gerais da actividade administrativa definidos nesse diploma são aplicáveis «a toda a actuação da Administração, ainda que meramente técnica...».

Não será, por outro lado, exagero qualificar de importante contributo para a concretização do princípio do Estado de Direito o $\mathrm{n}^{\mathrm{o}} 1$ do art. $151^{\circ}$ do Código do Procedimento Administrativo, o qual determina que «salvo em estado de necessidade, os órgãos da Administração Púbica não podem praticar nenhum acto ou operação material de que resulte limitação de direitos subjectivos ou interesses legalmente

Sobre as dificuldades na delimitação do que deve ser, nos nossos dias, o âmbito da reserva estadual de tarefas próprias da satisfação de pretensões integrantes do status positivus do cidadão, v., a título de exemplo, GRAMM, Privatisierung und notwendige Staatsaufgaben, Berlin: Duncker \& Humblot, 2001, p. 366 s. Para significar o conjunto dos âmbitos materiais em que a Administração cessou a actividade prestadora mas assegura, através do exercício de poderes de regulação, uma satisfação equitativa das correspondentes necessidades pelo mercado, a doutrina alemã cunhou recentemente o termo Gewährleistungsverwaltung (administração de garantia de prestações). V. DETTERBECK, ob. cit., p. 5. Este conceito não se concilia com a anterior dicotomia entre administração de prestação (Leistungsverwaltung) e fiscalização da actividade económica pelo Estado. Transcende-a porque se trata de um novo modo de ordenação conjunta de efectivação privada de prestações e de garantia estadual aos cidadãos quanto ao preenchimento de determinados standards de satisfação. Cfr. HOFFMANN-RIEM/SCHMIDT-ASSMANN/VOSSKUHLE, Grundlagen des Verwaltungsrechts, I, p. 987.

${ }^{17}$ Cfr., a título de exemplo, WOLFF (WILFRIED), Allgemeines Verwaltungsrecht, Baden-Baden, Nomos: 1986, pp. 301 ss. Precisamente porque estes actos são qualificáveis juridicamente em função da relação jurídica em cujo âmbito são praticados, onde podem figurar como actos preparatórios ou de execução de actos administrativos, actos de satisfação de direitos de particulares em face da Administração, actos de desempenho de deveres funcionais da Administração (relevantes nas relações internas) e assim sucessivamente, GIANNINI rejeita a expressão acto material ou actividade material, por poder ser erroneamente entendida numa acepção ajurídica (Cfr. Diritto Amministrativo, II, Milano: Giuffrè, 1988, pp. 443 e 444 ).

Estamos porém em crer que a expressão actos reais, que GIANNINI prefere e corresponde à tradução literal do alemão Realakte, poderia entre nós induzir em outro tipo de confusão. Importa, isso sim, sublinhar que estes actos, que não comportam uma declaração e por essa razão se não dirigem a produzir efeitos por eles próprios definidos, nem por isso são alheios ao Direito, visto que o Direito os contempla como objecto de regulação. Sobre operação material ou acto técnico, praticados «sem intenção de produção de efeitos jurídicos imediatos», cfr. MARCELLO CAETANO, Manual de Direito Administrativo, I, 10 a ed., Lisboa: Coimbra Editora, 1973, pp. 435 e 438; CARLA AMADO GOMES, Contributo para o Estudo das Operações Materiais da Administração Pública e do seu Controlo Jurisdicional, Coimbra: Coimbra Editora, 1999, p. 263 e 264. 
protegidos dos particulares, sem terem praticado previamente o acto administrativo que legitime tal actuação». Embora inserida numa Secção sobre execução do acto administrativo, a regra transcrita não se limita, obviamente, às situações de imposição do cumprimento de obrigações e do respeito pelas limitações que derivam de um acto administrativo. Ela estabelece um princípio de alcance mais largo: o do acoplamento necessário entre a operação material que afecte situações subjectivas activas e uma prévia decisão jurídica que, tendo-a por objecto, sirva de elemento de referência do respectivo regime jurídico e de base para o seu controlo administrativo e jurisdicional.

Muito embora as operações de prestação, enquanto actos meramente favorecedores, não estejam abrangidas pela regra em questão, nada impede que elas sejam também antecedidas de um acto administrativo que enquadre a conduta fáctica num instrumento jurídico de aplicação normativa.

Embora os actos materiais de administração possam desempenhar funções muito diversas à luz das quais é possível estabelecer uma tipologia diversificada ${ }^{18}$, uma sua parte significativa concentra-se nas actividades prestadoras, onde assumem a natureza de prestações de facto ou de coisa que constituem objecto mediato de relações jurídicas administrativas.

As relações jurídicas administrativas de prestação de cuidados de saúde.

6. Preferimos referir no plural «relações jurídicas administrativas de prestação de cuidados de saúde» por nos parecer problemática a verificação no âmbito contemporâneo do Direito Administrativo da Saúde de condições para configurar a estrutura interna de uma relação jurídica paradigmática. Parece por isso mais prudente falar em «relações» em face de diferenças decorrentes de particularismos orgânicos e funcionais.

Mas a insusceptibilidade da recondução de todas as situações de prestação administrativa de cuidados de saúde a um modelo único e invariável de relação jurídica administrativa não significa que se não encontrem em todas elas importantes elementos relacionais comuns. Esses elementos definem-se em função de vários círculos concêntricos, de âmbito sucessivamente mais restrito.

Em primeiro lugar, há que tomar em conta a definição, por elementos normativos da Ordem Jurídica portuguesa, de direitos próprios de todas as pessoas que recebem cuidados de saúde. É o caso dos direitos proclamados pela Convenção para Proteç̧ão dos Direitos do Homem e da Dignidade do Ser Humano Face às Aplicações da Biologia e da Medicina, ratificada por Decreto do Presidente da República $n^{\circ} 1 / 2001$, de 20 de Fevereiro, que entrou em vigor na ordem jurídica portuguesa em 1 de Dezembro de 2001. Ali se estabelece a favor de toda a pessoa o direito ao consentimento livre, esclarecido e revogável perante intervenções no domínio da saúde (art. $5^{\circ}$ ) e o direito ao respeito pela vida privada no que toca a informações relacionadas com a própria saúde (art. $10^{\circ}$ ), a par de outros. Também a Lei no 12/2005, de 26 de Janeiro, imputa às pessoas em geral os direitos nela declarados nos domínios

${ }^{18}$ Cfr. MAURER, Allgemeines Verwaltungsrecht, p. 411; WOLFF/BACHOF/STOBER, Verwaltungsrecht, II, München: Beck, 2000, p. 273-277; CARLA AMADO GOMES, Contributo para o Estudo das Operações Materiais ..., cit., p. $232 \mathrm{~s}$. 
da informação genética pessoal e informação de saúde. É o caso do direito do titular da informação de saúde de fazer depender da sua autorização ou de quem o represente a respectiva utilização pelo sistema de saúde (art. $4^{\circ}, n^{\circ} 3$ ).

Um segundo círculo - sobreposto ao anterior, mas de âmbito mais restrito - é o formado pelos utentes do sistema de saúde. Esta categoria compreende a dos utentes do Serviço Nacional de Saúde, mas não apenas. Com efeito, a par do SNS, o sistema de saúde abrange todas as entidades públicas que, não dependentes do Ministério da Saúde, desenvolvam actividades de promoção, prevenção e tratamento na área da saúde, bem como todas as entidades privadas e todos os profissionais livres que acordem com o SNS a prestação de todas ou de algumas daquelas actividades (Lei $n^{\circ}$ 48/90, de 24 de Agosto, de Bases da Saúde - doravente Lei de Bases, Base XII, $\mathrm{n}^{\circ}$ 1). Ora a Base XIV da Lei de Bases enuncia, no seu $\mathrm{n}^{\circ} 1$, um pormenorizado catálogo de direitos dos utentes do sistema de saúde e, no respectivo $\mathrm{n}^{\circ} 2$, um elenco de deveres dos mesmos. Sirvam de exemplo, o direito de se ser tratado «pelos meios adequados, humanamente e com prontidão, correç̧ão técnica, privacidade e respeito» (Base XIV, $\mathrm{n}^{\circ} 1$, alínea c) ) e o dever de «observar as regras sobre a organização e o funcionamento dos serviços e estabelecimentos» (idem, $\mathrm{n}^{\circ}$ 2, alínea b) ).

Um novo círculo, concêntrico mas mais reduzido quanto ao conteúdo específico do seu regime relacional, é o Serviço Nacional de Saúde (SNS). No quadro deste, é ainda preciso distinguir as relações de prestação de cuidados de saúde aos utentes beneficiários e aos utentes não beneficiários. Esta distinção será comentada adiante. Mas assinala-se desde já que só aos beneficiários se aplica o regime das taxas moderadoras e das suas isenções ou reduções (Decreto-Lei n ${ }^{\circ}$ 79/2008, de 8 de Maio) ao passo que, quanto aos meros utentes, se impõe o dever de pagamento dos cuidados prestados pela integralidade do respectivo preço (Lei de Bases, Base XXXIII, $\mathrm{n}^{\circ} 2$, alínea c), e Estatuto do SNS, aprovado pelo Decreto-Lei $n^{\circ}$ 11/93, de 15 de Janeiro, tal como revisto pelo Decreto-Lei ${ }^{\circ}$ 401/98, de 17 de Dezembro, art. $25^{\circ}$ ).

Os regimes das relações jurídicas administrativas de prestação de cuidados de saúde aos utentes beneficiários do SNS ramificam-se, ainda no plano legislativo, em função das diferentes instituições e estruturas prestadoras. E diversificam-se, por fim, nas partes em que ganham contornos específicos à luz do regulamento interno de cada uma dessas pessoas colectivas ou dos seus serviços.

Assim, o art. $4^{\circ}$ do Regime Jurídico da Gestão Hospitalar, aprovado pela

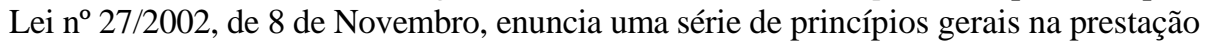
de cuidados de saúde com inegável perfil subjectivável (liberdade de escolha do estabelecimento hospitalar, prestação com humanidade e respeito pelos utentes, atendimento de qualidade e em tempo útil, cumprimento das normas de ética e deontologia profissionais).

Por seu turno, o Regime Jurídico dos Centros de Saúde, aprovado pelo Decreto-Lei no 157/99, de 10 de Maio, (revogado pelo Decreto-Lei no 60/2003, mas repristinado pelo Decreto-Lei no 88/2005) estrutura-se em torno de «unidades funcionais» cujas distintas valências implicam conteúdos ao menos parcialmente distintos para relações de prestação diversas. Assim, as unidades de saúde familiar prestam «cuidados 
de saúde de forma personalizada» «a uma população identificada através da inscrição em listas de utentes» (art. 12 ${ }^{\circ} \mathrm{n}^{\text {os }} 1$ e 2). As unidades de cuidados na comunidade prestam «cuidados de enfermagem e de apoio psicossocial de base geográfica e domiciliária, com identificação e acompanhamento das famílias com situação de maior risco ou vulnerabilidade de saúde, em especial quando existam grávidas, recém-nascidos, pessoas com marcada dependência física e funcional ou com doenças que requeiram acompanhamento mais próximo e regular» (art. $13^{\circ}, \mathrm{n}^{\circ} 1$ ). As unidades de meios de diagnóstico e tratamento e de especialidades prestam os seus cuidados específicos em apoio às unidades de saúde familiar e de cuidados na comunidade. As unidades de internamento prestam cuidados de saúde em internamento de sede comunitária, tendo como principais destinatários os doentes convalescentes com altas hospitalares precoces, os doentes necessitando de cuidados paliativos, os doentes em situação de agudização de doenças crónicas, os doentes com doença aguda necessitando de cuidados e vigilância que não possam ser garantidos no domicílio ou os doentes em fase de reabilitação (art. $16^{\circ}, \mathrm{n}^{\circ} 1$ ). Por fim, as unidades básicas de urgência prestam cuidados com carácter urgente, articulando-se com a rede nacional de urgência e emergência (art. $17^{\circ}, n^{\circ} 1$ ).

Esta multiplicidade de valências não se manifesta apenas ao nível das peculiaridades dos actos ou operações materiais. Fatalmente, implica também a modulação das situações subjectivas activas e passivas dos utentes. O mesmo se diga quanto à prestação de cuidados continuados integrados no âmbito da Rede Nacional de Cuidados Continuados Integrados a favor de pessoas em situação de dependência: o art. $7^{\circ}$ do Decreto-Lei $n^{0} 101 / 2006$, de 6 de Junho, enuncia a tal propósito um elenco de direitos da pessoa em situação de dependência, incluindo, por exemplo, os direitos à preservação da identidade, à não discriminação ou ao exercício da cidadania, a par dos direitos comuns à dignidade, à privacidade e ao consentimento informado.

Quanto às diversas formulações legislativas de elementos das situações jurídicas dos destinatários das prestações administrativas de cuidados de saúde, deve ter-se presente que se não trata apenas do desdobramento formal por diversos diplomas da enunciação de princípios, direitos e deveres comuns. Estes surgem com efeito repetidamente. Mas, a par deles, outros aparecem cuja peculiaridade permite caracterizar distintos tipos de relações de prestação.

Estas peculiaridade poderão ser ampliadas no plano da normação regulamentar. A lei estabelece, com efeito, competência regulamentar sobre o funcionamento interno dos órgãos das entidades prestadoras. Assim, o art. $6^{\circ}, \mathrm{n}^{\circ} 1$, alínea e), do Decreto-Lei $n^{\circ}$ 188/2003, de 20 de Agosto, (regime dos hospitais do sector público administrativo) concede aos conselhos de administração destes hospitais o poder de «definir as regras atinentes à assistência prestada aos doentes, assegurar o funcionamento harmónico dos serviços de assistência e garantir a qualidade e prontidão dos cuidados de saúde prestados pelo hospital». Por seu turno, o art. $13^{\circ}, n^{\circ} 2$, alínea a), do Decreto-Lei ${ }^{\circ}$ 298/2007, de 22 de Agosto, atribui ao Conselho Geral de cada Unidade de Saúde Familiar - USF (um dos tipos de cuidados funcionais dos Centros de Saúde) a competência para aprovar o respectivo regulamento interno. E, de acordo com o art. $10^{\circ}, \mathrm{n}^{\circ} 2$, do mesmo diploma, o regulamento interno consagra, nomeadamente, 
o horário de funcionamento e de cobertura assistencial, o sistema de marcação de consultas e de renovação de prescrições, o acolhimento orientação e comunicação com os utentes e a carta de qualidade.

Também sucede que - tratando-se embora do regulamento interno de uma entidade prestadora (o qual deverá, portanto, conter normas adequadas à resposta aos condicionalismos peculiares de natureza sócio-económica e geográfica), a competência de aprovação caiba ao Governo. É aquilo que sucede com o regulamento interno de cada Centro de Saúde, o qual, de acordo com o ${ }^{\circ} 1$ do art. $8^{\circ}$ do Decreto-Lei $n^{\circ} 157 / 99$, de 10 de Maio, é aprovado por portaria do Ministro da Saúde.

Quanto a este ponto, pode, pois, concluir-se que o regime das relações jurídicas administrativas de prestação de cuidados de saúde no âmbito do SNS tem uma dupla fonte legislativa e regulamentar. A nível legislativo, notam-se peculiaridades de conformação em função dos tipos de instituições prestadoras, não obstante o peso uniformizador do estatuto dos utentes do sistema de saúde, tal como arquitectado na Base XIV da Lei de Bases. A peculiarização dos regimes será naturalmente acentuada por força das disparidades que se possam encontrar na normação regulamentar emitida para cada instituição.

7. Um ponto comum às relações jurídicas administrativas de prestação de cuidados de saúde é o seu carácter não contratual. Não cremos com efeito que o acto criador da relação de utilização de, por exemplo, um Centro de Saúde seja bilateral, isto é, que nele se materialize um acordo de vontades ${ }^{19}$. O utente, ou alguém por ele, requer uma consulta, a qual deverá ser-lhe concedida de acordo com o princípio da máxima acessibilidade possível, traduzido em atendimento no próprio dia e marcação de consulta para hora determinada (Regime dos Centros de Saúde, estabelecido pelo Decreto-Lei $n^{\circ} 157 / 99$, de 10 de Maio, art. $\left.9^{\circ}, n^{\circ} 1\right)^{20}$. À formulação da pretensão corresponderá, portanto, uma decisão de concessão imediata de consulta ou de marcação de consulta. Eventualmente, em articulação com uma consulta, poderá ser determinado um internamento em hospital ou em unidade de internamento do próprio centro de saúde ${ }^{21}$.

São deste modo praticados actos administrativos ampliativos, sob solicitação do particular ou antecedidos do seu consentimento (no caso de internamento). O valor das vontades manifestadas pelo particular e pela Administração de Saúde e o conteúdo

\footnotetext{
${ }^{19}$ No sentido de que, regra geral, o acto criador da relação de utilização dos serviços públicos pelos particulares tem a natureza de contrato administrativo, v. FREITAS DO AMARAL, Curso de Direito Administrativo, I, $2^{\text {a }}$ ed., Coimbra, 1994, p. 630. Estaremos de acordo quanto àqueles casos em que a intervenção inicial do particular assuma um carácter co-constitutivo da relação jurídica de prestação.

${ }^{20}$ O Decreto-Lei $n^{\circ}$ 157/99, de 10 de Maio, foi revogado pelo Decreto-Lei $n^{\circ}$ 60/2003, de 1 de Abril, e repristinado pelo Decreto-Lei $\mathrm{n}^{\circ} 88 / 2005$, de 3 de Junho.

${ }^{21}$ Nos termos do art. $16^{\circ}, \mathrm{n}^{\circ} 1$, do Decreto-Lei $\mathrm{n}^{\circ} 157 / 99$, de 10 de Maio, a unidade de internamento do centro de saúde é uma unidade prestadora de cuidados de saúde em internamento de sede comunitária, tendo como principais destinatários: a) os doentes convalescentes com altas hospitalares precoces; b) os docentes necessitados de cuidados paliativos, sem condições para serem cuidados no próprio domicílio; c) os doentes em situação de agudização de doenças crónicas; d) os doentes com doença aguda necessitando de cuidados e vigilância que não possam ser garantidos no domicílio; e) os doentes em fase de reabilitação após doença aguda ou agudização de doença crónica.
} 
das faculdades e poderes exercidos não se equiparam. A declaração do particular cria um pressuposto de uma decisão positiva ou negativa ${ }^{22}$. Mas só à vontade da Administração de Saúde cabe gerar os efeitos de direito pretendidos, através de um acto pelo qual verifica e declara (ainda que a declaração possa ser implícita) a titularidade pelo requerente dos requisitos legais e o inscreve num plano de fruição dos serviços. Estes são poderes da Administração, ligados à gestão dos estabelecimentos de saúde do SNS, em cujo exercício não faria sentido chamar os particulares a comparticipar individualizadamente ${ }^{23}$. No plano estrutural, a marcação de consulta ou a decisão de internamento são manifestações unilaterais da vontade da Administração, constitutivas de uma relação específica de prestação de serviços (cuidados) de saúde, que se articulam com manifestações de vontade do particular. Estas últimas constituem requisitos de validade ou de eficácia da decisão administrativa, consoante esta dependa legalmente de um pedido prévio ou do consentimento do utente, quando este deva ou possa ser posterior ao acto ainda que anterior à respectiva execução material ${ }^{24}$.

8. A situação de direito público do utente das unidades de saúde do SNS tem carácter legal e regulamentar. Os utentes (Lei no 48/90, Bases XIV e XXV) encontram-se, nessa sua qualidade, submetidos a um regime jurídico pré-estabelecido num plano normativo. Os seus direitos, faculdades, deveres e sujeições resultam, por um lado, de princípios gerais aplicáveis a todo o utente de serviços públicos: direitos ao funcionamento do serviço, de acesso ao serviço, ao funcionamento correcto do serviço, à igualdade no tratamento. A estas situações jurídicas de conteúdo muito amplo, somam-se outras, específicas para os utentes do SNS, como as que resultam das Bases V e XIV da Lei $n^{\circ}$ 48/90 e de normas de legislação diversa. Entre estes direitos enquanto utente, releva particularmente, para efeitos de intervenção cirúrgica, o direito à informação sobre os tempos máximos de resposta garantidos de acordo com a Carta dos Direitos de Acesso (Lei n ${ }^{\circ} 41 / 2007$, de 24 de Agosto, arts. $2^{\circ}$ e $3^{\circ}$ ).

O estatuto do utente do SNS é também integrado pelos textos de carácter regulamentar como se referiu anteriormente.

O utente não pode pretender determinar por acordo com o estabelecimento modalidades específicas para as suas relações com este último, a não ser nos casos, certamente raros (se é que chegam a existir), em que se não infrinja desse modo o princípio geral da igualdade de tratamento dos utentes dos serviços públicos. Por isso, as relações jurídicas entre ambos são conformadas ou directamente por normas, ou por actos administrativos que têm essas normas por matriz. Uma substituição do

\footnotetext{
${ }^{22}$ Em princípio, o poder decisório da Administração é vinculado, visto que o particular terá direito à consulta na sua qualidade de beneficiário do Serviço Nacional de Saúde (Lei nº 48/90, de 24 de Agosto, Base XIV, $\mathrm{n}^{\circ}$ 1). Mas critérios de repartição territorial de competências, ou outros de carácter organizatório, poderão ditar uma decisão de indeferimento por parte de um certo estabelecimento.

${ }^{23}$ Já faria sentido aceitar a co-participação na gestão dos estabelecimentos de associações representativas de utentes dos SNS, as «entidades que os representem e defendam os seus interesses» previstas pela alínea h) do ${ }^{\circ} 1$ da Base XIV da Lei $n^{\circ}$ 48/90, de 24 de Agosto (Lei de Bases da Saúde).

24 Sobre o modo de distinguir os contratos administrativos dos actos administrativos carecidos de colaboração, v. SÉRVULO CORREIA, Legalidade e Autonomia Contratual nos Contratos Administrativos, Coimbra, 1987, pp. 344-350.
} 
acto administrativo por contrato, escorada no princípio da alternatividade entre estas duas formas típicas de conduta administrativa, encontraria uma barreira impeditiva na ressalva da parte final do art. $278^{\circ}$ do Código dos Contratos Públicos: «... salvo se outra coisa resultar da lei ou da natureza das relações a estabelecer». Neste caso, a natureza das relações a estabelecer associa-se estreitamente com o princípio da igualdade de tratamento, que não permitiria uma diversificação contratualizada do grau de qualidade dos cuidados prestados aos utentes.

9. A situação do utente tem pois um carácter geral e estatutário: não pode ser derrogada por acordo, nem lhe poderão ser introduzidas discriminações positivas ou negativas, a não ser naqueles casos em que a lei, fundada em critérios materiais que lhe salvaguardam a constitucionalidade, assim o determine. A situação do utente é livremente modificável (mas em termos gerais e não individualizados) por lei, regulamento ou acto administrativo dotado de habilitação normativa. Isto porque essa situação é «objectiva», não no sentido de o particular não ser titular de direitos subjectivos em face do SNS, mas no de esses direitos serem aqueles que as normas jurídicas em cada momento vigentes determinarem ${ }^{25}$.

No tocante à modificalidade por lei destas relações jurídicas, e, portanto, do âmbito, pressupostos e objecto das prestações que elas envolvam, advertiu MARCELLO CAETANO que «... quando razões de justiça e equidade o imponham, o legislador deverá prever nas leis que modificam a utilização do serviço os problemas resultantes, para os já inscritos, da transição de regimes, mediante disposições transitórias» ${ }^{26}$. Com efeito, a alteração de direitos já constituídos (e não das meras expectativas) encontra como limite o princípio da tutela da confiança dos administrados, que é uma das vertentes do princípio do Estado de Direito. No mínimo, a restrição ou abolição dos direitos a determinadas prestações valerá para o futuro, dificilmente podendo afectar prestações já efectivadas sem violação do princípio da protecção da confiança ${ }^{27}$.

\section{OS SUJEITOS.}

\section{A Administração prestadora.}

10. Escapa ao objecto do presente estudo a caracterização dos sujeitos públicos das relações jurídicas sobre as quais nos debruçamos. Neste campo da Ordem Jurídica portuguesa, a técnica legislativa está longe da perfeição desejável e a multiplicação de figuras graças às inovações legislativas tem vindo reforçar o perfil labiríntico da rede nacional de prestação de cuidados de saúde a que alude o $\mathrm{n}^{\circ} 4$ da Base XII da Lei de Bases de Saúde (Lei no 48/90, de 24 de Agosto). Limitamo-nos, pois, a esclarecer que, ao mencionar genericamente a Administração prestadora enquanto sujeito das relações jurídicas aqui versadas, pretendemos incluir desde logo as pessoas colectivas públicas que integram o SNS, mas não só. Há, por exemplo, que ter presente que,

${ }^{25}$ Cfr. AUBY (JEAN-MARIE), Le Droit de la Santé, Paris, 1981, p. 399 ; FLEINER-GERSTER, Rechtsverhältnisse in der Leistungsverwaltung, in Veröffentlichungen der Vereinigung der Deutschen Staatsrechtslehrer, $\mathrm{n}^{\circ}$ 45, 1987, pp. 159 e 167-168; MARCELLO CAETANO, Manual de Direito Administrativo, $9^{\text {a }}$ ed., Lisboa, 1972, p. 1057.

${ }^{26}$ Ob. cit., p. 1057.

${ }^{27}$ Cfr. BLANKE, Vertrauenschutz im deutschen und europäischen Verwaltungsrecht, Tübingen: Mohr, 2000, p. 199 e 200. 
com a nova redacção do $n^{\circ} 3$ da Base XXXVI da Lei no 48/90, de 24 de Agosto, se passou a permitir ao legislador a criação de unidades de saúde com a natureza de sociedades anónimas de capitais públicos ${ }^{28}$. E, no entanto, o Regime jurídico da gestão hospitalar aprovado pela Lei $n^{\circ} 27 / 2002$, de 8 de Novembro, aplica-se a todos os hospitais integrados na rede de prestação de cuidados de saúde (art. $1^{\circ}, \mathrm{n}^{\mathrm{o}} 1$ ). Figuram assim a par, para efeito deste regime, os hospitais com a natureza de estabelecimento público e aqueles que assumem a forma de sociedade anónima de capitais exclusivamente públicos, bem como, aliás, os hospitais que sejam estabelecimentos privados mas com os quais hajam sido celebrados contratos de colaboração $^{29}$. Com efeito, de acordo com o art. $36^{\circ}$ do Decreto-Lei ${ }^{\circ} 185 / 2002$, de 20 de Agosto, sobre parcerias em saúde, em regime de gestão e financiamento privados, aplica-se com as necessárias adaptações o disposto para o contrato de gestão aos estabelecimentos de saúde pertencentes a outras entidades mas integrados no SNS mediante contrato de colaboração. Ora, do regime do contrato de gestão faz parte o importante princípio de que a entidade gestora assegura as prestações de saúde nos termos dos demais estabelecimentos que integram o SNS (art. $9^{\circ}, n^{\circ} 1$ ). Em suma, a natureza privada da entidade gestora não prejudica a aplicabilidade às prestações de cuidados de saúde do regime de prestações do SNS. É o próprio legislador a deixar claro estar-se perante uma situação típica de exercício de função administrativa por entidade privada.

Resta acrescentar que os Centros de Saúde são pessoas colectivas de direito público, a menos que se integrem numa associação de centros de saúde, caso em que é a esta última que assiste tal atributo (Decreto-Lei $\mathrm{n}^{\circ}$ 157/99, de 10 de Maio, arts. $3^{\circ}$, $\mathrm{n}^{\circ} 1$, e $10^{\circ}, \mathrm{n}^{\text {os }} 2$ e 3). Mas o Decreto-Lei ${ }^{\circ} 157 / 99$ não se aplica aos centros de saúde a partir do momento em que passem a estar integrados em agrupamentos de centros de saúde (ACES), nos termos do art. 42 do Decreto-Lei $\mathrm{n}^{\circ}$ 28/2008, de 22 de Fevereiro. O legislador caracteriza os ACES como serviços públicos de saúde com autonomia administrativa, constituídos por unidades funcionais formadas por um ou mais centros de saúde, que têm por missão garantir a prestação de cuidados de saúde primários à população de determinada área geográfica (Decreto-Lei $n^{\circ}$ 28/2008, art. $\left.2^{\circ}, n^{\circ} 1\right)$. Trata-se de uma figura de contornos dúbios, mas por certo abrangida pelo regime de prestações do SNS.

Também a autonomia organizativa e funcional que caracteriza as unidades de saúde familiar (USF) em nada prejudica a sua sujeição ao regime comum de prestação de cuidados de saúde do SNS, visto que têm por missão essa prestação aos respectivos utentes enquanto tais e que constituem um tipo de unidade funcional dos centros de saúde (Decreto-Lei no 298/2007, de 22 de Agosto).

Por seu turno, a Rede Nacional de Cuidados Continuados Integrados não é mais, no que toca à prestação de cuidados de saúde, do que um modo de funcionamento conjugado de hospitais e centros de saúde com o objectivo de proporcionar reabilitação,

\footnotetext{
${ }^{28}$ A nova redacção da Base XXXVI resulta da Lei n. ${ }^{\circ}$ 27/2002, de 8 de Novembro.

${ }^{29}$ Sobre as quatro figuras que podem revestir os hospitais integrados na rede de prestação de cuidados de saúde, ver o art. $2^{\circ}$, ${ }^{\circ} 1$, do Regime Jurídico da Gestão Hospitalar.
} 
readaptação, reintegração social ou conforto e qualidade de vida a pessoas em situação de dependência (Decreto-Lei no 101/2006, de 6 de Junho).

Este pois, grosso modo, o conspecto de modalidades organizatórias que assume o pólo administrativo prestador nas relações jurídicas administrativas de prestação de cuidados de saúde no âmbito do SNS. A sua visão mais completa e pormenorizada teria de resultar de um outro estudo, centrado numa perspectiva jurídica organizatória, que não é a nossa no presente trabalho.

\section{Os utentes e beneficiários.}

11. De acordo com o art. $64^{\circ}, \mathrm{n}^{\mathrm{os}} 1$ e 2, alínea a), da Constituição, todos têm direito à protecção da saúde, o qual é realizado, no plano institucional, através de um serviço nacional de saúde universal e geral e, tendo em conta as condições económicas e sociais dos cidadãos, tendencialmente gratuito.

A um leitor desprevenido, poderia parecer que, na Lei de Bases da Saúde (Lei $n^{0}$ 48/90, de 24 de Agosto), o legislador usa como sinónimos os termos utentes (por exemplo, nas Bases XIV e XXIV, alínea d)) e beneficiários (por exemplo, nas Bases XXV e XXXV, $\mathrm{n}^{\circ} 1$ ). E, de facto, por vezes assim é: quando, por exemplo, na alínea c) da Base XXIV, se declara que o SNS se caracteriza por ser tendencialmente gratuito para os utentes, o legislador pensa por certo nas pessoas abrangidas na definição de beneficiários contida na Base XXV. Mas como o universo dos beneficiários não é ilimitado e como passagens do tipo da alínea c) do $\mathrm{n}^{\circ} 2$ da Base XXXIII mostram que não há o propósito de vedar o acesso a não-beneficiários, logo se depreende que o conceito de utente, abrangendo todos os beneficiários, tem, pelo menos quando empregue com rigor, um âmbito mais largo. A alínea a) do $\mathrm{n}^{\circ} 1$ do art. $23^{\circ}$ do Estatuto do Serviço Nacional de Saúde (aprovado pelo Decreto-Lei no 11/93, de 15 de Janeiro) demonstra que assim é, ao falar de «utentes não beneficiários dos SNS» para estatuir que estes respondem pelos encargos resultantes da prestação de cuidados de saúde.

Com a definição de beneficiários, a Base XXV da Lei de Bases da Saúde desempenha a função de densificar os todos do art. 64 ${ }^{\circ}, \mathrm{n}^{\circ} 1$, da Constituição. Segundo aquela Base, os todos que têm direito à protecção da saúde através do SNS são os cidadãos portugueses, os cidadãos nacionais de Estados membros das Comunidades Europeias, nos termos das normas comunitárias aplicáveis e, ainda, os cidadãos estrangeiros residentes em Portugal, em condições de reciprocidade, e os cidadãos apátridas residentes em Portugal.

Estas são, pois, as categorias que conferem, sem reservas nem ressalvas, capacidade jurídica para entrar em relação de prestação de cuidados de saúde com os estabelecimentos do SNS, na qualidade de utente deste serviço público. Isto não significa que tais estabelecimentos não possam - e não devam, ao menos em situações de urgência - tratar pessoas que escapem àquele quadro subjectivo. E nem sequer em tal eventualidade poderá cada estabelecimento regular com autonomia as condições de prestação dos serviços.

Com efeito, da leitura conjugada dos arts. $13^{\circ}, n^{\circ} 1$, e $15^{\circ}, n^{\circ} 1$, da Constituição, resulta que os estrangeiros não beneficiários do SNS hão-de receber os cuidados nos mesmos termos em que eles são prestados aos beneficiários (que são, em primeiro 
lugar embora não só, os cidadãos portugueses). Mas, quanto aos encargos resultantes da prestação de cuidados aos não beneficiários, dispõe o art. $23^{\circ}, n^{\circ} 1$, alínea a) do Estatuto do Serviço Nacional de Saúde que por eles respondem tais utentes não beneficiários.

O utente beneficiário do SNS não entra em relação jurídica só por força desta qualificação normativa. A qualidade de beneficiário é um simples pressuposto da entrada em relação para efeito de prestação de cuidados. Mas o início de cada relação depende de actos ou factos concretos, como adiante se verá. Por outras palavras, os direitos e obrigações que integram cada relação específica nascem com o início da situação de utilização.

\section{O CONTEÚDO.}

\section{Breve perfil da figura.}

12. Como escreve MARCELO REBELO DE SOUSA, «é o conteúdo que empresta uma fisionomia própria à situação jurídica» ${ }^{30}$. Esta asserção é extensível à relação jurídica, que constitui um agregado de situações jurídicas através das quais uma pessoa se encontra imediatamente ligada a outra ou outras. Uma vez desencadeada uma relação jurídica de prestação de cuidados de saúde, o utente do SNS adquire imediatamente direitos e obrigações que resultam da sua situação estatutária, podendo outros direitos e obrigações ir-lhe sendo criados ao longo do desenrolar da relação por força de actos administrativos ou de outros actos ou factos no quadro do ordenamento estatutário ${ }^{31}$.

Algumas das situações do utente são caracterizáveis como direitos subjectivos públicos. Estes traduzem-se no poder, protegido por uma norma de direito público, de exigir uma conduta de objecto certo por parte de um órgão ou agente de uma pessoa colectiva pública, ou privada mas incumbida do exercício de função administrativa de gestão pública. Através dessa conduta, satisfazem-se simultaneamente um interesse público posto por lei a cargo da pessoa pública e um interesse do particular também ele tutelado pela norma de competência. A tais direitos correspondem deveres de prestação de serviços (actos materiais de exercício das artes médica e paramédica e de hotelaria) ou de coisas (actos materiais de entrega de medicamentos ou alimentos) por parte do estabelecimento do SNS que se encontra em relação com o particular.

Alguma vezes, porém, a bilateralidade da relação jurídica não é tão sinalagmaticamente nivelada. Na realidade, quando o poder da Administração é discricionário, a correspondente situação jurídica do particular é apenas a de um interesse legalmente protegido. Ao particular não assiste o poder de exigir uma conduta administrativa de objecto certo graças a uma pré-determinação normativa. Mas, como a conduta administrativa irá conformar interesses seus a que a lei não recusa tutela, considera-se o particular como especificamente ofendido pela violação das normas jurídicas que regulam o iter procedimental e o iter cognoscitivo e valorativo conducentes à decisão ${ }^{32}$.

${ }^{30}$ Cfr. MARCELO REBELO DE SOUSA/SOFIA GALVÃO, Introdução ao Estado do Direito, 1991, p. 192.

${ }^{31}$ Cfr. MOREAU/TRUCHET, ob. cit., p. 137.

${ }^{32}$ Cfr. ACHTERBERG, Allgemeines Verwaltungsrecht, cit., pp. 391-392 ; FLEINER-GERSTER, ob. cit., pp. 165 e 172-179. 
Sobre este ponto, uma primeira ideia, que a reflexão mais atenta infirma, é a de que a latitude das opções quanto à terapêutica a adoptar para cada caso clínico alicerçaria um amplo campo de discricionariedade administrativa no âmbito das relações jurídicas públicas de prestação de cuidados de saúde. Na realidade, não é assim. Neste domínio, a margem de discricionariedade é escassa porque os utentes têm um verdadeiro direito subjectivo ao tratamento pelos meios adequados e com prontidão e correcção técnica (Lei n 48/90, de 24 de Agosto, Base XIV, nº 1 , alínea c)). A esse direito corresponde um dever do hospital ou do centro de saúde. Só que este dever jurídico de prestar um facto material ${ }^{33}$ tem por objecto uma prestação genérica. Trata-se da prestação de um serviço médico e ou de um serviço paramédico cuja determinação ( também chamada individualização ou concentração) assiste à entidade devedora e é efectuada por esta em cada momento, através dos seus agentes habilitados para a prática de tais actos, à luz das circunstâncias do caso clínico ${ }^{34}$.

Ao exercício deste poder-dever de determinação do objecto preciso de cada acto médico é que poderia provavelmente caber com propriedade (tal como na individualização do objecto de outros deveres de efectivação de actos materiais pela administração prestadora) a designação de discricionariedade técnica, que, entre nós, se tem usado, sob influência italiana, com rigor científico questionável, para especificar outra realidade ${ }^{35}$. Quando o médico do SNS opta entre a sujeição do utente a radioterapia ou a quimioterapia, ou lhe prescreve certos comprimidos em vez de outros alternativamente concebíveis, ele age discricionariamente. Mas esta discricionariedade não é jurídica. A conduta administrativa em causa cifra-se na prática de um acto material. Não pode por isso falar-se de discricionariedade administrativa enquanto modo de conformação jurídica, ou seja, de margem de liberdade na produção de efeitos de direito. Em contrapartida, o termo discricionariedade técnica parece apropriado: a liberdade de opção do médico não é total, não se confunde com arbítrio. Ela rege-se por leis científicas e considerações de ordem técnica, que integram as chamadas leges artis. Faz pois sentido qualificar como técnica a margem de livre determinação da prestação de facto. E parece correcto o emprego do termo

${ }^{33}$ Quanto a este conceito, v. ANTUNES VARELA, Das Obrigações em Geral, I, 7 $7^{\mathrm{a}}$ ed., Coimbra, 1991, pp. 62 e 85.

${ }^{34}$ Cfr. MENEZES CORDEIRO, Direito das Obrigações, I, Lisboa, 1990, pp. 341 e 342.

${ }^{35}$ O Supremo Tribunal Administrativo tem usado o conceito de discricionariedade técnica para caracterizar condutas administrativas onde uma margem de livre apreciação apenas se mostra passível de controlo jurisdicional do erro manifesto ou erro grosseiro de apreciação.

Estas situações não se confundem com as de verdadeira discricionariedade porque o que nelas está em causa não é o preenchimento pela Administração de uma abertura da norma jurídico-administrativa quanto ao sentido da decisão, que poderá ser vinculado. A impropriamente chamada discricionariedade técnica limita-se à realização de um juízo valorativo ou de prognose. Através de tal juízo, decide-se (em vez de verificar subsuntivamente) sobre se um elemento da situação da vida que a Administração é chamada a conformar preenche um pressuposto formulado na factispecies da norma jurídico-administrativa com emprego de um conceito jurídico indeterminado. Sobre esta matéria, cfr. SÉRVULO CORREIA, Legalidade e Autonomia Contratual nos Contratos Administrativos, cit., pp. 475-478; Separation of Powers and Judicial Review of Administrative Decisions in Portugal, in ZOETHOUT/VAN DER TANG/AKKERMANS (ed), Control in Constitucional Law, Dordrecht-Boston-London, 1993, pp. 180-183; Conceitos jurídicos indeterminados e âmbito do controlo jurisdicional, in: Cadernos de Justiça Administrativa, n. ${ }^{\circ} 70$ (JulhoAgosto de 2008), p. 32 s. 
discricionariedade porque - na grande maioria, se não mesmo na totalidade dos casos - os conhecimento científicos e técnicos não libertam o agente administrativo-médico de prognosticar, ponderar e escolher entre soluções nenhuma das quais se deva considerar excluída à partida.

Mas o facto de se estar num plano de decisões regidas por critérios de técnica extra-jurídica não significa que deparemos com uma discricionariedade juridicamente ilimitada. A discricionariedade técnica apenas existe quando as opções alternativas sejam igualmente admissíveis. Se, pelo contrário, forem infringidas regras de ordem técnica ou deveres objectivos de cuidado, a conduta torna-se ilícita. O órgão ou agente da Administração encontra-se portanto vinculado a não a adoptar ( $\operatorname{art.} 9^{\circ}, \mathrm{n}^{\circ} 1$, do Regime da Responsabilidade Civil Extracontratual do Estado e Demais Entidades Públicas, aprovado pela Lei ${ }^{\circ}$ 67/2007, de 31 de Dezembro). Para além do plano disciplinar, as consequências da inobservância de standards de ordem técnica claramente imperativos manifestam-se no campo da responsabilidade administrativa.

Além disso, as consequências fácticas do acto material não poderão revelar manifesta discrepância com os princípios fundamentais da actividade administrativa, como resulta do $\mathrm{n}^{\circ} 5$ do art. $2^{\circ}$ do Código do Procedimento Administrativo. A determinação da incompatibilidade de uma decisão técnica com algum desses princípios obriga a concluir pela ilicitude da conduta para todos os efeitos próprios. Pelo menos nalguns casos, a manifesta violação de um tal princípio - designadamente a de máximas da proporcionalidade - coincidirá com a desobediência às leges artis.

\section{Direitos do utente.}

13. A Lei de Bases da Saúde (Lei no 48/90) considera separadamente os direitos dos cidadãos no tocante à saúde e os direitos dos utentes do sistema de saúde. O sistema de saúde é constituído pelo Serviço Nacional de Saúde e por todas as entidades públicas que desenvolvam actividades de promoção, prevenção e tratamento na área da saúde, bem como por todas as entidades privadas e por todos os profissionais livres que acordem com o SNS a prestação de todas ou de algumas daquelas actividades (Base XII, $\mathrm{n}^{\circ} 1$ ). Assim sendo, os direitos dos utentes do sistema de saúde valem, designadamente, no âmbito das relações entre o SNS e os seus utentes.

Nos termos da Base $\mathrm{V}, \mathrm{n}^{\circ}$ 2, «os cidadãos têm direito a que os serviços públicos de saúde se constituam e funcionem de acordo com os seus legítimos interesses». Encontramos aqui a afirmação expressa pelo nosso legislador de um princípio geral do Direito dos serviços públicos, de há muito detectado pela doutrina e pela jurisprudência.

Um serviço público diz-se obrigatório quando uma norma jurídica impõe a sua existência. No caso vertente, não estamos perante uma daquelas múltiplas situações em que o legislador ordinário impõe à Administração pública a constituição e a manutenção de certo serviço público. Nessas outras hipóteses, a recusa ou a negligência na criação podem constituir o administrado em legitimidade para a propositura de acção de declaração de ilegalidade por omissão de normas (CPTA, art. $77^{\circ}$ ) e de responsabilidade por omissão ilícita (Regime de Responsabilidade, 
art. $\left.7^{\circ}, n^{\circ} 1\right)^{36}$. Mas, entre nós, o imperativo de constituição de um serviço nacional de saúde universal e geral é constitucional e dirige-se à Assembleia da República, ao Governo e às Assembleias Legislativas das Regiões Autónomas como órgãos da função legislativa (Constituição, arts. $64^{\circ}, n^{\circ} 2$, alínea a), $165^{\circ}, n^{\circ} 1$, alínea f) e $227^{\circ}$, $\mathrm{n}^{\circ} 1$, alínea c) e $232^{\circ}, \mathrm{n}^{\mathrm{o}} 1$ ). De todo o modo, uma vez cumprido pelo legislador esse comando constitucional, os indivíduos abrangidos pelo universo do SNS têm um direito juridicamente exequível ao funcionamento «de acordo com os seus legítimos interesses», ou seja, na base da organização racional dos meios à luz dos fins de prestação de utilidades que justificam o próprio imperativo constitucional de existência do serviço ${ }^{37}$.

14. Referindo-se ao sistema de saúde, dispõe por seu turno o $\mathrm{n}^{\circ} 1$ da Base XIV: «1 - Os utentes têm direito a:

a) Escolher, no âmbito do sistema de saúde e na medida dos recursos existentes e de acordo com as regras de organização, o serviço e agentes prestadores;

b) Decidir receber ou recusar a prestação de cuidados que lhe é proposta, salvo disposição especial da lei;

c) Ser tratados pelos meios adequados, humanamente e com prontidão, correcção técnica, privacidade e respeito;

d) Ter rigorosamente respeitada a confidencialidade sobre os dados pessoais revelados;

e) Ser informado sobre a sua situação, as alternativas possíveis de tratamento e a evolução provável do seu estado;

f) Receber, se o desejarem, assistência religiosa;

g) Reclamar e fazer queixa sobre a forma como são tratados e, se for caso disso, a receber indemnização por prejuízos sofridos;

h) Constituir entidades que os representem e defendam os seus interesses;

i) Constituir entidades que colaborem com o sistema de saúde, nomeadamente sob a forma de associações para promoção e defesa da saúde ou de grupos de amigos de estabelecimentos de saúde.»

A liberdade de escolher o serviço e os agentes prestadores prende-se com o direito de acesso, um direito potestativo de iniciar uma relação concreta de prestação de cuidados de que trataremos adiante, a propósito do início das relações.

Do ponto de vista do conteúdo da relação, a passagem fundamental do preceito transcrito é a alínea c). Ao reconhecer aos utentes o direito de serem tratados «pelos meios adequados» "com correcção técnica», o legislador remete para as regras da arte, em cujo âmbito é densificado em cada momento o objecto do direito do utente e do dever do estabelecimento. Com esses parâmetros de ordem técnica articulam-se estreitamente os deveres deontológicos dos médicos e pessoal paramédico.

${ }^{36}$ Cfr. LAUBADÈRE/VENEZIA/GAUDEMET, Traité de Droit Administratif, I, cit., p. 686.

${ }^{37}$ Cfr. LAUBADĖRE/VENEZIA/GAUDEMET, idem, ibidem; MARCELLO CAETANO, Manual de Direito Administrativo, II, cit., pp. 1055-1058. 
O utente tem direito a receber a prestação de cuidados em termos que não comprometam a respectiva qualidade. Tem direito a ser diagnosticado e tratado à luz de conhecimentos tecnicamente actualizados. Tem direito a que o seu diagnóstico seja estabelecido com o máximo cuidado, a que as prescrições sejam formuladas com clareza e a que as terapêuticas perfilhadas o não façam correr riscos desnecessários ${ }^{38}$.

Ao reconhecer um direito do utente do SNS ao tratamento pelos meios adequados, com prontidão, correcção técnica e respeito, a lei portuguesa vai além do que prescreve a Convenção para a Protecção dos Direitos do Homem e da Dignidade do Ser Humano face às Aplicações da Biologia e da Medicina do Conselho da Europa, que entrou em vigor na Ordem Jurídica portuguesa em 1 de Dezembro de 2001. Dispõe esta, no seu art. $3^{\circ}$, que «as Partes tomam, tendo em conta as necessidades de saúde e os recursos disponíveis, as medidas adequadas com vista a assegurar, sob a sua jurisdição, um acesso equitativo aos cuidados de saúde de qualidade apropriada». Tudo indica tratar-se de uma regra objectiva de comportamento político-administrativo e não directamente de uma norma de protecção capaz de investir sujeitos de direito em pretensões subjectivadas e justiciáveis.

15. A densificação do conteúdo do direito ao tratamento, feita através da remissão para as regras da arte, encontra um non plus ultra natural «na medida dos recursos existentes» (Base XIV, $\mathrm{n}^{0} 1$, alínea a)), ou seja, «nos limites dos recursos humanos, técnicos e financeiros disponíveis» (Base $\mathrm{I}, \mathrm{n}^{\circ} 2$ 2). Simplesmente, este desfasamento entre necessidades colectivas e recursos obriga os órgãos dos estabelecimentos responsáveis pela aprovação dos planos de acção e linhas de orientação sobre organização e funcionamento a uma criteriosa ponderação da afectação dos recursos, por modo a que prioridades vitais não sejam preteridas a favor de outras de nível secundário. Sob pena de responsabilidade jurídica, designadamente a administrativa por actos de gestão pública, não poderá, por exemplo, descurar-se a manutenção do equipamento de diálise renal sacrificando os recursos a isso indispensáveis a utilizações de que não dependa tão directamente a preservação das vidas dos utentes.

Em matéria de tanta delicadeza, afigura-se que a margem de livre decisão dos órgãos dos estabelecimentos de saúde na afectação de recursos escassos deveria ser limitada pelo legislador, na medida do tecnicamente possível. Não só se aliviaria dessa maneira uma responsabilidade potencialmente pesada dos titulares dos órgãos dos estabelecimentos. Obter-se-ia além disso um outro resultado ainda mais importante: o de assegurar melhor a igualdade de acesso dos utentes a recursos escassos. A restrição da discricionariedade na utilização de meios de tratamento particularmente onerosos através da densificação normativa dos pressupostos da sua utilização e dos factores de seriação preferencial dos utentes neles interessados constituirá por certo um meio particularmente indicado de prossecução do «objectivo fundamental», enunciado na alínea b) do $\mathrm{n}^{\circ} 1$ da Base II da Lei de Bases da Saúde, de «obter a

${ }^{38}$ Cfr. MOREAU/TRUCHET, ob. cit., p. 125 ; LAUFS (Adolf), Artz und Recht im Wandel der Zeit, in Recht und Medizin, ed. Por ALBIN ESER/ALFRED KÜNSCHNER, Darmstadt, 1990, pp. 409-412; MONTGOMERY, Jonathan, Health Care Law, $2^{\mathrm{a}}$ ed., Oxford: University Press, 2003, p. 167 s. 
igualdade dos cidadãos no acesso aos cuidados de saúde, seja qual for a sua condição económica e onde quer que vivam, bem como garantir a equidade na distribuição de recursos e na utilização de serviços» ${ }^{39}$.

No tocante, por exemplo, àquilo que toca à gestão hospitalar, o legislador limita-se a incluir na competência do conselho de administração a definição «das regras atinentes à assistência prestada aos doentes, assegurar o funcionamento harmónico dos serviços de assistência e garantir a qualidade e prontidão dos cuidados de saúde prestados pelo hospital» (art. $6^{\circ}, \mathrm{n}^{\circ} 1$, alínea e), do Decreto-Lei $\mathrm{n}^{\circ}$ 188/2003, de 20 de Agosto). Esta ampla discricionariedade regulamentar com óbvia incidência na conformação do acesso aos cuidados apenas será limitada do exterior pelo exercício da tutela governamental e, sobretudo, pela Carta dos Direitos de Acesso, publicada anualmente sob a forma de portaria. Nos termos da Lei no 41/2007, de 24 de Agosto, esta define os tempos máximos de resposta garantidos para todo o tipo de prestações sem carácter de urgência e o direito dos utentes à informação sobre os mesmos. De acordo com o $\mathrm{n}^{\circ} 3$ do art. $3^{\circ}$ da Lei $\mathrm{n}^{\circ} 41 / 2007$, cada estabelecimento do Serviço Nacional de Saúde fixará anualmente, tomando como referência a portaria, os seus tempos de resposta garantidos por tipo de prestação e de patologia ou grupo de patologias, os quais deverão constar dos respectivos planos de actividade e contratos-programa.

\section{Direitos e poderes da administração de saúde.}

16. $\mathrm{O} \mathrm{n}^{\circ} 2$ da Base XIV da Lei de Bases da Saúde estabelece por seu turno uma lista de deveres dos utentes:

a) Respeitar os direitos dos outros utentes;

b) Observar as regras sobre a organização e o funcionamento dos serviços e estabelecimentos;

c) Colaborar com os profissionais de saúde em relação à sua própria situação;

d) Utilizar os serviços de acordo com as regras estabelecidas;

e) Pagar os encargos que derivam da prestação dos cuidados de saúde, quando for caso disso.

Estes deveres têm como contrapartidas, do lado da Administração de Saúde, nuns casos direitos e noutros poderes de autoridade.

17. Ao dever de pagamento de encargos, previsto na alínea e), corresponde um direito de cobrança dos estabelecimentos, respeitante, nomeadamente, às taxas moderadoras.

No texto do art. $64^{\circ}$ da Constituição saído da revisão de 1989, passou a constar que, sendo tendencialmente gratuito, além de universal e geral, o Serviço Nacional de Saúde tem em conta as condições económicas e sociais dos cidadãos. É de entender a

\footnotetext{
${ }^{39}$ Sobre a extrema dificuldade em concluir sobre acesso equitativo ou sobre igualdade de acesso, a qual começa pela própria objectivação da ideia de «acesso», se complica graças ao carácter não-homogéneo das estruturas prestadoras e depende de parâmetros de justiça distributiva, v. DANIELS, Norman, Just Health Care, Cambridge: University Press, Reimpressão de 1995, p. 59 s.
} 
partir desta passagem da lei fundamental que, embora os cuidados do SNS devam ser gratuitos tanto quanto o permita a situação financeira do Estado, não terão de sê-lo absolutamente. E a imputação do dever de efectuar pagamentos em correlação com cuidados prestados e a modulação dos respectivos montantes não deverão ser alheias às condições económicas dos utentes.

A Lei de Bases prevê diversas espécies de dever de pagamento. $\mathrm{O} \mathrm{n}^{0} 1$ da Base XXXIV dispõe que «com o objectivo de completar as medidas reguladoras do uso dos serviços de saúde, podem ser cobradas taxas moderadoras, que constituem também receita do Serviço Nacional de Saúde». O n 2 acrescenta que dessas taxas «são isentos os grupos populacionais sujeitos a maiores riscos e os financeiramente mais desfavorecidos, nos termos determinados na lei». Resulta da alínea d) do $\mathrm{n}^{0} 2$ da Base XXXIII que estas taxas tanto poderão respeitar à prestação de serviços como à utilização de instalações ou equipamentos, nos termos legalmente previstos. As taxas moderadoras estão hoje reguladas pelo Decreto-Lei $n^{0} 79 / 2008$, de 8 de Maio. Este diploma tipifica as prestações de saúde que implicam o respectivo pagamento: exames complementares de diagnóstico e terapêutica, com excepção dos efectuados em regime de internamento; serviços de urgência hospitalares e dos centros de saúde; consultas (art. $\left.1^{\circ}, \mathrm{n}^{\circ} 1\right)$. O valor das taxas moderadoras é aprovado por portaria do Ministro da Saúde e revisto e actualizado anualmente. Elas não podem exceder um terço dos valores constantes da tabela de preços do SNS. A par deste modo de observância da directriz constitucional do carácter tendencialmente gratuito, um outro consiste na isenção de pagamento de taxas moderadoras em favor de certas categorias mais desprotegidas por razões de ordem social ou de saúde (por exemplo, os desempregados inscritos nos centros de emprego e os insuficientes renais crónicos) (art. $\left.2^{\circ}, n^{\circ} 1\right)$. Também os utentes com idade igual ou superior a 65 anos beneficiam de uma redução de $50 \%$ do pagamento (artigo $\left.2^{\circ}, n^{\circ} 2\right)^{40}$.

Nas não é este o único tipo de pagamento que, segundo aquela lei, poderá constituir objecto de dever por parte dos utentes: a alínea a) do $\mathrm{n}^{\circ} 2$ da Base XXXIII admite a cobrança do pagamento de cuidados em quarto particular ou outra modalidade não prevista para a generalidade dos utentes. E a alínea g) tipifica como receita do SNS «o produto da efectivação de responsabilidade dos utentes por infracções às regras da organização e do funcionamento do sistema e por uso doloso dos serviços e do material de saúde».

18. São ainda deveres dos utentes respeitar os direitos dos outros utentes, observar as regras sobre a organização e o funcionamento dos serviços e estabelecimentos, colaborar com os profissionais de saúde em relação à sua própria situação e utilizar os serviços de acordo com as regras estabelecidas (alíneas a) a d) do $\mathrm{n}^{\circ} 2$ da Base XIV). Tais deveres constituem o quadro de referência para o exercício de poderes de autoridade, por parte dos órgãos dos estabelecimentos do SNS, sobre os utentes envolvidos em relações de prestação de cuidados de saúde.

40 Sobre a jurisprudência do Tribunal Constitucional em matéria de taxas moderadoras, v. CASALTA NABAIS, Jurisprudência do Tribunal Constitucional em matéria Fiscal, in Boletim da Faculdade de Direito de Coimbra, Vol. LXIX, 1993, pp. 399-400. 
Na doutrina estrangeira, encontra-se ainda hoje com alguma frequência a afirmação de que os utentes dos serviços públicos se colocam sob um estatuto especial, que envolve obrigações e sujeições distintas das que incidem sobre os outros administrados. Tal estatuto revestiria, segundo certos sectores da doutrina germânica, a natureza de relação especial de poder (besonderes Gewaltverhältnis) ${ }^{41}$. Já em ocasião anterior expusemos as razões pelas quais rejeitamos este conceito, fruto de uma visão prussiana dos finais do século XIX, desejosa de encontrar fundamentos para subtrair zonas de actividade administrativa à reserva de lei em matéria de restrições aos direitos fundamentais. Na Alemanha contemporânea, a ideia foi posta em cheque pela evolução da jurisprudência constitucional, que lhe negou qualquer função de dispensa de tal reserva. Posto isto, o conceito perdeu função operativa própria e os autores que se não dispõem a colocá-lo simplesmente de lado limitam-se a reconhecer-lhe o valor de categoria classificatória de certas relações jurídicas com características comuns ${ }^{42}$.

A nosso ver, porém, não faz sentido dividir as relações jurídico-administrativas que servem de matriz ao exercício de poderes públicos em «relações gerais» e «relações especiais». Tal sistematização teria porventura alguma razão de ser se correspondesse à localização no seio do Direito Administrativo especial das normas que presidissem às relações «especiais». Mas o sentido atribuído a relações especiais de poder tem sido um outro, muito mais restrito, mais ou menos correspondente a uma «vinculação a deveres especialmente agravados» ${ }^{43}$.

Não pensamos que esta ideia baste para justificar uma categoria jurídica autónoma, isto é, que sirva para delimitar um estatuto particular de sujeição. O eminente relativismo do carácter mais ou menos gravoso dos deveres não confere uma base suficientemente objectiva para a demarcação de um regime específico ${ }^{44}$.

GARCÍA DE ENTERRÍA e TOMÁS-RAMÓN FERNÁNDEZ explicam nos seguintes termos a distinção entre «poderes de supremacia geral e de supremacia especial (ou inseridos numa relação geral ou especial de poder)»:

«Os primeiros sujeitam todos os cidadãos graças à condição abstracta destes enquanto súbditos do poder público, sem necessidade de títulos concretos.

\footnotetext{
${ }^{41}$ Sobre o conceito de relação especial de poder, v.: ACHTERBERG, Allgemeines Verwaltungsrecht, cit., pp. 384-387; INGO VON MÜNCH, Verwaltung und Verwaltungsrecht, in, ERICHSEN/MARTENS, Allgemeines Verwaltungsrecht, 7. a ed., Berlim-Nova Iorque, 1986, pp. 50-53; MAURER, Allgemeines Verwaltungsrecht, 9. ${ }^{\mathrm{a}}$ ed., Munique, 1994, pp. 105.

${ }^{42}$ Cfr. INVO VON MÜNCH, ob. cit., p. 53. Sobre a nossa oposição ao emprego de tal figura, desprovida de raízes na cultura juspublicista portuguesa, vide SÉRVULO CORREIA, Legalidade e Autonomia Contratual nos Contratos Administrativos, Coimbra, 1987, pp. 71 e 104.

${ }^{43}$ Cfr. MARIA JOÃO ESTORNINHO, Requiem pelo Contrato Administrativo, Coimbra, 1990, p. 167.

44 É o que transparece da posição de FREITAS DO AMARAL. O ilustre administrativista acolhe o conceito de relações especiais de poder, logo no entanto se sentido forçado a opinar que a disciplina jurídica própria dessa situação típica não é a mesma para as várias categorias de administrados que nela considera merecerem inclusão.

Mas se o conceito não serve para delimitar situações abrangidas por um regime nuclear comum, quais a sua função e a sua utilidade?

Cfr. Curso de Direito Administrativo, I, cit., p. 629.
} 
Os segundos apenas são exercitáveis sobre quem se encontre numa situação organizatória determinada de subordinação, derivada de um título concreto: sobre os funcionários ou os utentes dos serviços públicos (assim, o poder disciplinar, os soldados, os presos, etç)» ${ }^{45}$.

A distinção parece-nos - salvo o devido respeito - arbitrária. Em abstracto, todos os cidadãos se encontram sujeitos a todos os poderes administrativos. Para que a barreira entre o abstracto e o concreto, entre o virtual e o real, seja transposta, torna-se precisa a produção sucessiva de dois fenómenos. Um facto ou acto jurídico há-de ter por efeito individualizar um cidadão como destinatário necessário ou possível do exercício de um poder administrativo numa situação de vida. Assim se estabelece, no plano material ou substantivo, uma relação jurídico-administrativa. Seguidamente ${ }^{46}$, desencadear-se-á um procedimento administrativo ao longo do qual o poder abstracto - ou seja, a competência - se converterá em acto.

Tanto sentido faz pois afirmar que o cidadão Abel poderá vir a ser sujeito ao exercício de um poder de expropriação desde que venha a possuir um imóvel cuja utilidade pública se vier a patentear, como dizer que Abel poderá ser sujeito a qualquer poder próprio de uma direç̧ão de hospital público sobre os respectivos utentes desde que o seu estado de saúde venha a provocar o seu internamento num desses estabelecimentos. Em qualquer das hipóteses, os poderes administrativos em causa não dependem, como figuras abstractas, do tráfico jurídico, isto é, da criação ou modificação de relações jurídicas concretas, nem recaiem, na sua abstracção, sobre uns cidadãos mais do que sobre outros. Em qualquer delas, aquilo que provoca o exercício do poder é a verificação, na vida real, de uma situação correspondente aos pressupostos enunciados na facti species da norma jurídica que o configura. Todos os cidadãos terão de admitir que uma expropriação poderá eventualmente recair sobre os seus bens ou que lhes poderá ser proibido que consumam bebidas alcoólicas num hospital onde se encontrem internados. Não vemos razões para poder afirmar com rigor científico que, no primeiro caso, haverá uma relação geral de poder e, no segundo, uma relação especial. Em ambos, existem poderes de autoridade configurados pelo ordenamento jurídico-administrativo, que poderão vir a ser exercidos sobre qualquer sujeito de direito que vier a encontrar-se numa situação subsumível na previsão das normas que os conferem.

Estas considerações aplicam-se aos poderes disciplinares da Administração, que não são mais «especiais» do que quaisquer outros poderes de autoridade. Como os outros, nascem de normas jurídico-administrativas de competência e destinam-se à prossecução de interesses públicos. Como os outros, tornam-se exercitáveis quando uma situação da vida real quadra na previsão normativa.

Raro será hoje o campo de actuação administrativa relativamente ao qual a Administração não disponha de poderes sancionatórios. E se é certo que se justifica a autonomia conceitual da espécie sanção disciplinar no seio do género constituído

${ }^{45}$ Cfr. Curso de Derecho Administrativo, I, $11^{\text {a }}$ ed., Madrid, 2002, p. 446.

${ }^{46}$ Embora, por vezes, a prioridade lógica da primeira possa dispensar a sequência cronológica entre a formação da relação jurídico-administrativa substantiva e o início do procedimento administrativo. 
pela sanção administrativa, não é menos verdade que nem sequer existe uma tipologia homogénea das sanções disciplinares ${ }^{47}$. Não existindo pois um regime disciplinar comum, também não seria na existência de um segmento disciplinar em certas relações jurídico-administrativas que poderia pretender encontrar-se a coluna dorsal do esvaecido instituto das relações especiais de poder. Mas, mesmo que assim não fosse, deveria então falar-se simplesmente de relações abarcando poder disciplinar ${ }^{48}$.

Em suma, não pensamos que as relações jurídicas de prestação de cuidados de saúde nos serviços públicos de saúde mereçam ser qualificadas como relações especiais de poder. Deve, isso sim, reconhecer-se que tais relações envolvem a sujeição do utente a uma disciplina que constitui uma exigência do regular funcionamento do serviço público ${ }^{49}$.

\section{Limites dos poderes da administração de saúde.}

19. A relação jurídica de prestação de cuidados nos serviços públicos de saúde inclui ou reflecte poderes da Administração de saúde. Os poderes organizatórios incidem em boa medida sobre as condições do utente enquanto inserido na vida do serviço. Alguns poderes de direcção e de disciplina têm-no como destinatário directo. E a sujeição torna-se ampla e relevantíssima, por tocar no cerne de direitos de personalidade, quando o poder exercido se identifica com aquilo que atrás dissemos ser discricionariedade técnica em sentido próprio: a escolha, através da

${ }^{47}$ Cfr. CARLO PALIERO/ALDO TRAVI, La Sanzione Amministrativa, Milão, 1988, pp. 48-58.

${ }^{48}$ Sobre a tendência de evolução dos sistemas jurídicos no sentido da integração do poder disciplinar no poder sancionatório geral da Administração, v. GARCÍA DE ENTERRÍA/TOMÁS-RAMÓN FERNÁNDEZ, ob.cit., II, 8. ${ }^{\text {a }}$ ed., Madrid, 2002, p. 170.

${ }^{49}$ Cfr. AUBY, Le Droit de la Santé, cit., p. 399 ; DE SOTO, Droit Administratif - Théorie Générale du Service Public, Paris, 1981, p. 73.

A nosso ver, não cabe confundir relações especiais de poder com relações estatutárias. A estas últimas, chama-se por vezes relações de estatuto especial, entendendo-se como tais as que são próprias da condição jurídica de determinados círculos de pessoas sujeitas a regimes jurídicos diferenciados, ou seja, a estatuto especial. Mas esta expressão afigura-se-nos em alguma medida tantológica e, em última análise, imprópria.

A expressão é tantológica porque a noção de estatuto envolve sempre alguma especialidade. Não, necessariamente, no sentido de derrogação de um regime geral, mas da especificidade de um subsistema normativo estruturado sobre uma área de referência demarcada em função de fins, interesses e situações peculiares. É a este propósito que faz sentido falar de um estatuto do utente do sistema de saúde.

Mas, a par do seu carácter tantológico, a expressão estatuto especial envolve uma certa impropriedade quando com ela se pretende significar um tratamento diferenciado de alguns em relação ao conjunto dos cidadãos. Isso é particularmente ilustrado no nosso caso pela circunstância de utentes do sistema de saúde serem todos os cidadãos. Não faz, pois, sentido «especializar» um grupo demarcado que para o efeito da aplicabilidade objectiva das normas do subsistema, quer para o da titularidade subjectiva das situações jurídicas concretas que poderão resultar da aplicação daquelas em consequência da ocorrência de factos ou da prática de actos. Não são a aplicabilidade das normas nem as capacidades jurídicas que destas se refractam que são diferenciadas, mas tão somente as situações de aplicação por força das suas individualidade e concretude.

Em suma, estatuto sim. Estatuto especial não.

Sobre o conceito de relações de estatuto especial, v. MELO ALEXANDRINO, Direitos Fundamentais Introdução Geral, Estoril: Principia, 2007, p. 141 s. Note-se que o A. sublinha que «a integração de alguém numa relação de estatuto especial não afecta a titularidade de direitos fundamentais», «não estando excluído que essas relações também possam conduzir a um reforço da protecção dispensada às pessoas que nelas estão inseridas» (idem, p. 142 e 143). 
prática de um mero acto material, dos meios terapêuticos para o utente individualizado, feita pelos agentes médicos do SNS à luz das leges artis, temperadas pela necessidade de optimizar recursos escassos.

20. Estes poderes administrativos encontram, porém, sólidos limites em direitos fundamentais e direitos da personalidade.

Assim, aplicam-se também à administração da saúde os princípios gerais da conduta administrativa definidos no art. $266^{\circ}, \mathrm{n}^{\circ} 2$, da Constituição: igualdade, proporcionalidade, justiça e imparcialidade. Alguns destes princípios compreendem uma vertente subjectivada. Deste modo, é o direito fundamental à igualdade de tratamento, assente nos arts. $13^{\circ}$ e $266^{\circ}, n^{\circ} 2$, da Lei Fundamental, que a alínea d) da Base XXIV da Lei de Bases da Saúde densifica quando especifica que o SNS se caracteriza por «garantir a equidade no acesso dos utentes, com o objectivo de atenuar os efeitos das desigualdades económicas, geográficas e quaisquer outras no acesso aos cuidados».

$\mathrm{O}$ direito à reserva da intimidade da vida privada, consignado no art. $26^{\circ}, \mathrm{n}^{\mathrm{os}} 1$ e 2, da Constituição, é por seu turno concretizado na alínea d) do n. ${ }^{\circ} 1$ da Base XIV, que reconhece o direito dos utentes a «ter rigorosamente respeitada a confidencialidade sobre os dados pessoais revelados» ${ }^{50}$.

Algumas vertentes deste direito são particularizadas pela Convenção para a Protecção dos Direitos do Homem e da Dignidade do Ser Humano Face às Aplicações da Biologia e da Medicina (doravante Convenção do Conselho da Europa). Nos termos do $\mathrm{n}^{\circ} 1$ do respectivo art. $10^{\circ}$, «qualquer pessoa tem direito ao respeito da sua vida privada no que toca a informações relacionadas com a sua saúde». Mas a reserva de informação de dados de saúde para com terceiros tem como contrapartida o direito dos próprios à informação, quando assim o desejem. De acordo com o $\mathrm{n}^{\circ} 2$ do mesmo art. $10^{\circ}$, «qualquer pessoa tem o direito de conhecer toda a informação recolhida sobre a sua saúde. Todavia, a vontade expressa por uma pessoa de não ser informada deve ser respeitada».

Por outro lado ainda, a liberdade de religião e de culto é aplicada à relação de prestação de cuidados de saúde pela alínea f) do $n^{0} 1$ da Base XIV da Lei de Bases, que afirma o direito dos utentes a «receber, se o desejarem, assistência religiosa».

21. Mas, de todos os direitos fundamentais, aquele cuja condensação resulta em um perfil mais amoldado às particularidades da relação jurídica de prestação de cuidados de saúde é o que respeita à inviolabilidade da integridade moral e física das pessoas (Constituição, art. 25, $\mathrm{n}^{\circ}$ 1). Este direito fundamental - que é simultaneamente

${ }^{50}$ Como observa RITA AMARAL CABRAL, o direito à reserva sobre a intimidade da vida privada tutela a esfera da vida íntima (Geheimbereich), que compreende os gestos e factos que em absoluto devem ser subtraídos ao conhecimento de outrem. «O que significa que a privacidade compreenderá, por exemplo, o passado da pessoa, os seus sentimentos, factos atinentes à sua saúde, a respectiva situação patrimonial, os seus valores ideológicos e mesmo o seu domicílio que é, indiscutivelmente, o principal baluarte da intimidade da vida privada». Mas, como também sublinha a Autora, este direito compreende fundamentalmente o direito de oposição à divulgação (public disclosure) e não tanto à investigação sobre a vida privada (intrusion). Cfr. O Direito à Intimidade da Vida Privada, in Estudos em Memória do Professor Doutor Paulo Cunha, Lisboa, 1989, pp. 398, 399 e 403. 
um direito de personalidade ${ }^{51}$ - desdobra-se em dois direitos reconhecidos aos utentes pela Lei de Bases de Saúde: os direitos de «decidir receber ou recusar a prestação de cuidados que lhes é proposta, salvo disposição especial da lei» (princípio do consentimento necessário) (Base XIV, $\mathrm{n}^{0}$ 1, alínea b)) e de «ser informados sobre a sua situação, as alternativas possíveis de tratamento e a evolução provável do seu estado» (princípio do consentimento informado) (Base XIV, $\mathrm{n}^{\circ} 1$, alínea e)).

No seu art. $5^{\circ}$, a Convenção do Conselho da Europa combina os dois princípios sob a fórmula do consentimento livre e esclarecido, que deve anteceder qualquer intervenção no domínio da saúde. O mesmo preceito impõe a adequação da informação, explicitando que, para o ser, esta terá de dar a conhecer o objectivo e a natureza da intervenção, bem como as suas consequências e riscos. Por outro lado ainda, o consentimento deve ser revogável a todo o tempo.

22. O princípio do consentimento necessário exprime a liberdade do doente como pessoa humana em face das propostas de intervenção sobre o seu próprio organismo que recebe da Administração pública. Em regra, a vontade do doente deverá ser respeitada mesmo quando for no sentido da recusa de se deixar tratar. As excepções, sempre com base na lei (Constituição, art. $18^{\circ}$ ), só se justificarão naqueles casos em que o interesse da saúde pública tem de sobrepor-se ao arbítrio individual (vacinação obrigatória, exames obrigatórios, tratamentos obrigatórios no quadro da luta contra doenças epidémicas). A recusa só pode respeitar ao próprio interessado: se, com base em convicções filosóficas ou religiosas, os pais se opõem à realização de um tratamento reputado necessário para salvar a vida de um menor, a Administração tem o poder - dever de os impedir de cometer o crime de omissão de auxílio a pessoa em perigo (Código Penal, art. $219^{\circ}, \mathrm{n}^{\circ} 2$ ).

O princípio do consentimento necessário encontra tutela na figura do crime de intervenção e tratamento médico-cirúrgico arbitrários, consignado no art. $156^{\circ}$ do Código Penal. Salvo algumas excepções previstas no $\mathrm{n}^{\circ} 2$, a realização, por um médico ou outra pessoa legalmente autorizada a empreendê-los, de intervenções ou tratamentos sem consentimento do paciente será punível com prisão até três anos ou com pena de multa ${ }^{52}$.

23. Não basta, porém, um qualquer consentimento: é necessário um consentimento informado. Para além do respeito da pretensão de cada um ao conhecimento tão aprofundado quanto possível das coordenadas concretas do seu destino individual, é na necessidade de racionalizar o consentimento que assenta o direito dos utentes de serem informados sobre a sua situação, as alternativas possíveis de tratamento e a evolução provável do seu estado (Lei de Bases da Saúde, Base XIV, nº 1 , alínea e)). Este nexo é reconhecido expressamente pelo legislador que, no art. $157^{\circ}$ do Código Penal, estatui:

«Para efeito do disposto no artigo anterior, o consentimento só será eficaz quando o paciente tiver sido devidamente esclarecido sobre o diagnóstico

\footnotetext{
${ }^{51}$ Cfr. CARVALHO FERNANDES, Teoria Geral do Direito Civil, I, 1, Lisboa, 1983, p. 164.

${ }^{52}$ Sobre a aplicação princípio do consentimento necessário, v. MONTGOMERY, Health Care Law, cit., p. 227 s.
} 
e a índole, alcance, envergadura e possíveis consequências da intervenção ou do tratamento, salvo se isso implicar a comunicação de circunstâncias que, a serem conhecidas pelo paciente, poriam em perigo a sua vida ou seriam susceptíveis de lhe causar grave dano à saúde física ou psíquica» ${ }^{53}$.

24. Os direitos do utente em que se subjectivam os princípios da necessidade do consentimento e do consentimento informado pertencem à mesma família em que se integra o direito do utente a escolher, no âmbito do sistema de saúde, o serviço e os agentes prestadores, ainda que na medida dos recursos existentes e de acordo com as regras de organização (Lei de Bases da Saúde, Base XIV, $\mathrm{n}^{\circ} 1$, alínea a)). O valor subjacente a este direito reside também no respeito da integridade moral do doente, que não é compatível com a privação da liberdade de decisão sobre aspectos fundamentais do destino existencial de cada ser humano. A integridade moral compreende um direito fundamental de autonomia individual, ou seja, de decidir com autonomia sobre o se e o como do desenvolvimento da personalidade dentro dos limites postos por idênticos direitos dos outros e pela ordem constitucional ${ }^{54}$. E, para cada ser humano, o confronto com as crises patológicas do seu organismo e com a perspectiva da sua própria morte representa sem dúvida um filamento vital da personalidade.

\footnotetext{
53 O princípio do consentimento informado começou por ser afirmado a propósito da investigação médica efectuada sobre seres humanos (Código de Nuremberga de 1947 e Declaração de Helsínquia de 1964). A sua aceitação generalizou-se nas democracias ocidentais industrializadas a partir de meados da década de 70. Incide com particular importância em situações de tratamento que possam suscitar efeitos secundários graves e de terapia experimental, para além das de investigação pura. Mas a sua aplicação estende-se a todas as intervenções e tratamentos à luz da ideia de que a doença não priva as pessoas do seu livre arbítrio.

A plena efectividade do princípio depende inevitavelmente das circunstâncias objectivas de urgência e, também, da condição psicológica e cultural do doente. A este propósito escreve EUGENE BRODY:

«O «consentimento informado» é, sob o ponto de vista de muitos médicos acostumados a trabalhar sob pressão e a ter de tomar decisões rápidas na falta de informação adequada, um ideal que, dadas as necessidades psicológicas dos doentes quanto a orientação e atenção, a sua vulnerabilidade quanto ao influenciamento, mesmo o não intencional, e as necessidades de actuação dos próprios médicos, nunca poderá ser cem por cento atingido. É exigido e praticado de uma forma diferente num meio autoritário (quando aí tiver alguma aplicação) do que num meio igualitário, com doentes com habilitações escolares, provenientes de meios urbanos e da classe média, familiarizados com os direitos do consumidor do que com um camponês ou um operário semi-iletrado. O profissional da saúde encontra-se separado deste último por razões de estatuto sócio-económico e de conhecimento esotérico».

Este autor sublinha que os esforços de aplicação do princípio se defrontam também com os limites do conhecimento científico em cada período histórico: muitas vezes, os efeitos laterais indesejáveis dos tratamentos eram desconhecidos à data em que foram receitados.

E BRODY observa também que, como instituto jurídico, o consentimento informado continua submetido a um processo de lenta metamorfose que se prende com a múltiplas facetas da sua aplicação. Desde o problema da experimentação feita sobre doentes mentais, ao do recurso para fins de investigação terapêutica a membros - ainda que formalmente aquiescentes - de minorias desprotegidas, várias são as questões que têm dado lugar a debate e, por vezes, a processos judiciais. A proliferação de novos remédios ainda não suficientemente testados origina movimentações de grupos de pressão para a sua utilização antecipada (como tem sucedido no domínio da Sida), sem que sejam ainda claras, nos Estados Unidos, as consequências que daí poderão advir no tocante ao enquadramento jurídico dessas situações pela jurisprudência. Cfr. EUGENE BRODY, Biomedical Technology and Human Rights, Cambridge, 1993, pp. 20-23. Ver também MOREAU/TRUCHET, ob. cit., pp. 126 e 138-139; MONTGOMERY, Health Care Law, p. 242 s..

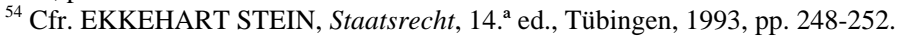


As relações jurídicas de prestação de cuidados e os deveres deontológicos dos agentes prestadores.

25. Nos termos mais depurados, a relação jurídica de prestação de cuidados de saúde no âmbito do SNS surge como uma relação bilateral. Esta relação tem um sujeito, dotado de personalidade jurídica e participante no SNS. E o sujeito privado é o utente, seja ele ou não um beneficiário do SNS.

À luz dos mais recentes desenvolvimentos da dogmática administrativa, parece no entanto legítimo duvidar de que este singelo esquema estrutural sirva para explicar toda a complexa trama de situações jurídicas que pode gerar a prestação de cuidados de saúde no âmbito institucional de que tratamos. Assim é particularmente no que toca ao posicionamento das situações jurídicas que se prendem com a deontologia dos profissionais de saúde que agem neste contexto.

Escreve a este propósito JEAN-MARIE AUBY que, na maioria dos casos, não existe qualquer relação contratual entre o utente e o médico, já que este último age no quadro do estatuto a que se encontra submetido no âmbito da pessoa colectiva pública a quem serve. E, por seu turno, o utente encontra-se também ele ligado à instituição prestadora por uma relação estatutária. Mas isso não impede - acrescenta AUBY que, nas relações que se estabelecem entre eles, o médico e o utente tenham obrigações não contratuais cuja violação pode acarretar responsabilidade. O ilustre Professor escreve ainda que as obrigações do médico resultam do seu estatuto administrativo ou do contrato que o liga ao serviço e refere, a par destas, a sujeição do clínico às regras deontológicas que sobre ele incidem por estar inscrito na Ordem dos Médicos, inscrição essa que constitui requisito indispensável da prática de actos médicos ${ }^{55}$.

Transposto para o caso do Serviço Nacional de Saúde português, o problema que o texto doutrinário assinalado deixa em aberto consiste em saber se a observância das regras deontológicas pelo pessoal de saúde do SNS no seu relacionamento com os utentes constitui situações jurídicas entre uns e outros ou se, pelo contrário, estas mantêm como únicos pólos de imputação a pessoa colectiva pública prestadora e o utente.

26. Em primeiro lugar, cremos de precisar que os direitos dos utentes se erguem perante o hospital, ou o centro de saúde, ou outra entidade prestadora, e não em face de cada elemento do pessoal médico ou paramédico. Alguns desses direitos envolvem, é certo, por parte de agentes da entidade prestadora, uma conduta conforme às regras deontológicas: respeito pelos princípios do consentimento e do dever de informar, respeito da confidencialidade sobre os dados pessoais revelados, tratamento adequado, humano, pronto e tecnicamente correcto, respeito pela pessoa do doente. Mas, reconhecidas como conteúdo de direitos pela Base XIV, $\mathrm{n}^{\circ} 1$, alíneas b), c) d) e e) da Lei de Bases, as condutas objecto de tal dever-ser inscrevem-se na relação jurídica do utente com o SNS. A pretensão do utente quanto a tais comportamentos dirige-se à entidade prestadora, sobre a qual incide o dever de preservar essas componentes da qualidade do serviço público prestado. De todo o modo, poderá em tais situações falar-se de direitos em sentido técnico-jurídico quando, do outro lado,

${ }^{55}$ Cfr. Le Droit de la Santé, cit., p. 251. 
for possível delimitar obrigações precisas, em face de um titular individualizado. Isto ainda quando essas obrigações sejam meramente acessórias de uma obrigação principal de prestação de cuidados médicos.

Ora, como observam os Professores JACQUES MOREAU e DIDIER TRUCHET, não cabe falar de um direito dos utentes ao respeito dos princípios deontológicos porque os códigos de deontologia apenas respeitam aos membros de uma profissão e a quem sobre eles exerça disciplina relativa aos comportamentos profissionais ${ }^{56}$. Por outras palavras, as regras deontológicas são parâmetros de valoração de condutas profissionais mais do que factores normativos de tipificação de prestações que possam por seu turno constituir objecto de direitos. Elas existem para satisfazer primariamente valores e interesses gerais. Só a sua violação pode gerar relações jurídicas tendo por conteúdo prestações de destinatário certo. Mas serão prestações indemnizatórias.

Em contrapartida, a relação de prestação de cuidados entre o utente e o hospital ou centro de saúde envolve sempre interesses legalmente protegidos daquele, criados à sombra das normas jurídicas que estabeleçam deveres deontológicos. O utente pode exigir do SNS que exerça os seus poderes directivos e disciplinares de modo a que os deveres deontológicos sejam acatados no decurso das relações de prestação em que é sujeito e destinatário.

Estas nossas conclusões assentam no disposto pela Lei de Bases da Saúde. De acordo com a Base XXXI, os profissionais de saúde que trabalham no SNS estão submetidos às regras próprias da Administração Pública, mas o seu estatuto é delimitado pela ética e deontologia profissionais. Mais do que de uma delimitação, trata-se, porém, de um interpenetração. Com efeito, o nº 4 da Base XXXII reconhece à Ordem dos Médicos a função de definição da deontologia e da qualidade técnica dos actos médicos praticados no âmbito do SNS. Por outro lado, o n ${ }^{\circ} 3$ desta Base faz depender de inscrição na Ordem dos Médicos o ingresso dos médicos e a sua permanência no SNS.

As regras deontológicas (Código Deontológico da Ordem dos Médicos) têm valor jurídico de regulamento administrativo, visto que emanam de uma associação pública dotada de competência normativa neste domínio. A observância dessas regras no âmbito da actividade prestadora das unidades de saúde do SNS constitui, pois, interesse legítimo ou interesse legalmente protegido do utente. O modo como esta situação jurídico-administrativa de natureza substantiva ou material se equaciona em termos de relacionamento é complexo. Por um lado, o art. $5^{\circ}$ do Código Deontológico da Ordem dos Médicos estatui que «o conhecimento da responsabilidade disciplinar dos médicos emergente de infracções à deontologia médica é da competência exclusiva da Ordem dos Médicos» e que «mesmo que as violações à deontologia médica se verifiquem em relação a médicos que exerçam a sua profissão em entidades públicas ... devem estas entidades limitar-se a comunicar as presumíveis infracções à Ordem dos Médicos». Se bem que um regulamento da Ordem dos Médicos não pudesse retirar competências a outras entidades administrativas, o problema resolveu-se graças à entrada em vigor do Decreto-Lei no 217/94, de 20 de Agosto. Este diploma

${ }^{56}$ Cfr. Droit de la Santé Publique, cit., p. 137. 
aprovou o Estatuto Disciplinar dos Médicos, cujo art. $1^{\circ}, \mathrm{n}^{\circ} 1$, determina que estão sujeitos à jurisdição disciplinar da Ordem dos Médicos todos os médicos inscritos na Ordem no momento da prática da infracção. E $o \mathrm{n}^{\circ} 1$ do art. $3^{\circ}$ acrescenta que a responsabilidade disciplinar perante a Ordem dos Médicos coexiste com quaisquer outras previstas por lei. Ainda, porém, que deva entender-se, perante o princípio non bis in idem, que a valoração das condutas à luz das regras deontológicas fica (no plano da função administrativa, que não no da função jurisdicional) confiada em exclusivo à Ordem dos Médicos, o Serviço Nacional de Saúde não pode descartar-se das suas atribuições disciplinares em relação a todos os seus agentes, essenciais ao regular funcionamento e ao asseguramento de certos direitos dos utentes. A verificação da violação específica dos deveres deontológicos, tal como enunciados no Código Deontológico da Ordem, será de exclusiva competência dos órgãos da associação pública. Mas os órgãos administrativos com competência disciplinar enquadrá-la-ão a título de pressuposto no exercício da sua própria competência de apreciação disciplinar de eventuais infracções de deveres gerais dos funcionários e agentes, como os de isenção, zelo, sigilo, correcção, assiduidade e pontualidade.

As considerações anteriores permitem compreender que, na medida em que a relação jurídica de prestação de cuidados envolve um interesse legítimo ou legalmente protegido do utente aos bens protegidos pelas regras deontológicas, ela é uma relação jurídica administrativa multipolar ou poligonal. Como é sabido, a multiplicidade e a diversidade deste tipo de relações jurídicas retrata a crescente complexidade das estruturas sociais do Estado pós-industrial ${ }^{57}$. A regulação administrativa acaba com frequência por envolver em necessária simultaneidade interesses poligonalmente seriados.

Imagine-se que uma utente, internada num hospital do SNS, considera que o médico a quem se encontra confiada não a trata com a "prontidão» e "correcção técnica» a que tem direito, nos termos da alínea c) do $n^{\circ} 1$ da Base XIV da Lei de Bases. Essa doente reclama para o conselho de administração do hospital, que exerce competência em matéria disciplinar (Decreto-Lei $n^{\circ}$ 188/2003, de 20 de Agosto, art. $6^{\circ}, \mathrm{n}^{\circ} 1$, alínea $\mathrm{m}$ )). O médico alega que o acto pretendido pela utente entra em conflito com a sua consciência moral, pelo que tem o direito de recusar a sua prática (art. $33^{\circ}$ do Código Deontológico). A utente considera por seu turno que, pela sua natureza, o acto pretendido é o tecnicamente adequado e não é de molde a poder razoavelmente gerar conflitos de consciência aos clínicos chamados a praticá-lo. Supondo que a razão assistia à utente, esta tinha, em primeiro lugar, em face da unidade de saúde, o direito a ver praticado o acto médico pretendido. Assistia-lhe, além disso, perante a Ordem dos Médicos, um interesse legalmente protegido à verificação constitutiva, por esta associação pública, da existência ou inexistência de um verdadeiro caso de consciência. Sem esse enquadramento do caso à luz do art. $33^{\circ}$ do Código Deontológico pela única autoridade com poderes para o fazer, não poderá o órgão hospitalar exercer por seu turno o seu poder directivo e disciplinar instrumentais à realização do interesse público e à concomitante satisfação do direito da utente.

${ }^{57}$ Cfr. ACHTERBERG, Allgemeines Verwaltungsrecht, cit., p. 373 ; GOMES CANOTILHO, Relações Jurídicas Poligonais, Ponderação Ecológica de Bens e Controlo Judicial Preventivo, in Revista Jurídica do Urbanismo e do Ambiente, $\mathrm{n}^{\circ}$ 1, Junho de 1994, pp. 55 segts. 
Mas a aludida regra deontológica e, conjuntamente com ela, os deveres de zelo e diligência próprios do estatuto dos agentes da Administração Pública criavam ainda à utente um interesse legalmente protegido relativamente à conduta do próprio médico. A destinatária do poder jurídico que assiste à utente de exigir um acto médico determinado é a unidade de saúde: é esta que deve a prestação do objecto do direito subjectivo público da doente. Contudo, as normas jurídicas que eventualmente vinculam o médico a tal conduta também conferem à utente um interesse juridicamente protegido em face do agente recusante. A entidade administrativa em cujo quadro o médico se insere não forma um écran absoluto entre ele e os utentes. Isso explica a sua responsabilidade de direito administrativo em face daqueles, em caso de dolo ou culpa grave, por força dos arts. $22^{\circ}$ da Constituição e $8^{\circ}$ do Regime da Responsabilidade Civil Extracontratual do Estado e Demais Entidades Públicas, aprovado pela Lei ${ }^{\circ}$ 67/2007, de 31 de Dezembro.

Em suma, a estrutura da relação jurídica administrativa de prestação, alargada em termos que lhe dêem uma forma poligonal, pode abarcar, em face do particular, não apenas a entidade administrativa competente para a prática do acto jurídico ou material de que este é destinatário, mas também outras entidades de cuja conduta dependa a possibilidade de emissão daquele acto e, ainda, os funcionários ou agentes dessas entidades, de cujo zelo funcional dependa o cumprimento de normas jurídicas administrativas que protejam par a par interesses públicos e um interesse do particular. A relação jurídica administrativa de prestação de cuidados de saúde disso dá um bom exemplo, mostrando também que os nexos que se entretecem em torno do binómio direito subjectivo público do utente e correspondente dever da Administração pública consistirão normalmente em uma correlação entre a sujeição de agentes da Administração a normas imperativas de conduta profissional e o reflexo interesse legítimo ou legalmente protegido do particular afectado por tal conduta.

\section{INÍCIO, DESENVOLVIMENTO E EXTINÇÃO.}

\section{Início.}

27. O modo como se configura juridicamente o início de uma relação jurídica de prestação de serviço público depende do carácter regulamentar ou contratual da mesma. Sustentámos, em momento anterior deste texto, que as relações jurídicas de prestação de cuidados de saúde pelas unidades de saúde do SNS possuem uma base normativa. Com a hipotética excepção de casos respeitantes a não beneficiários do SNS, estas relações não são portanto constituídas através de contrato, mas sim de facto ou acto jurídico.

Os administrativistas referenciam situações típicas em que o dever do serviço público de proporcionar as suas prestações nasce de um facto ${ }^{58}$. Assim será certamente quando uma pessoa dá entrada no serviço de urgência de um hospital em situação de inconsciência e é tratada sem qualquer procedimento administrativo prévio. Nas restantes situações, a relação jurídica de prestação de cuidados tem início por força de um acto administrativo.

${ }^{58}$ Cfr. MARCELLO CAETANO, Manual de Direito Administrativo, II, cit., p. 1056. 
A qualidade de beneficiário, delineada pela Base XXV da Lei $n^{\circ} 48 / 90$, não corresponde à participação numa única relação, tendencialmente vitalícia, tendo por objecto a fruição do serviço público de saúde. Trata-se apenas de um estatuto ou «estado» legal das pessoas incluídas nas categorias definidas por aquela norma em ordem à fruição do serviço público segundo um complexo de direitos, interesses legalmente protegidos, deveres e sujeições abstractamente estruturado pela lei ${ }^{59}$. A qualidade de beneficiário representa uma situação jurídica de origem directamente normativa e que, portanto, não depende da intermediação de qualquer acto da Administração. A função jurídica dessa qualidade não é muito vincada. Resume-se, ao fim e ao cabo, a dispensar um cadastro ou registo de utentes e uma inscrição no mesmo como pré-requisito do acesso à fruição e a permitir o tratamento diferenciado do acesso por parte dos estrangeiros e apátridas que não caiam sob a previsão da referida Base $\mathrm{XXV}^{60}$.

28. É variável a natureza do acto administrativo que determina o início da relação jurídica de prestação de cuidados de saúde por uma unidade de saúde do SNS.

Excepcionalmente, poderá tratar-se de uma ordem de internamento ou de prestação compulsiva de cuidados de saúde, desde que a lei dê competência específica para o efeito a um órgão ou agente da Administração de Saúde em relação a indivíduos em situação de prejudicarem a saúde pública (Lei nº 48/90, Base XIX, nº 1, alínea a)).

Normalmente, o acto administrativo que dá início à relação de prestação de cuidados satisfará um requerimento do interessado ou dependerá do seu consentimento para produzir efeitos. Neste plano, pode ainda tratar-se de dois distintos tipos de actos.

Para que estejamos em face de um acto de admissão propriamente dito, é necessário que o poder exercido seja discricionário, como sucederá com os internamentos hospitalares fora dos casos de urgência ou daqueles em que o momento do internamento é ditado pela ordem de inscrição numa «lista de espera».

Se cabe à Administração ponderar discricionariamente, à luz de pressupostos atinentes à condição do beneficiário do SNS e de outros, que retratam o grau de comprometimento do parque de camas em face das necessidades globais, a decisão de internamento é constitutiva: ela atribui um direito a alguém que possuía apenas um interesse legalmente protegido. Pode então com rigor dizer-se que se está perante um acto administrativo de admissão. Se, pelo contrário, o acto que regula a prestação

\footnotetext{
${ }^{59}$ Note-se que o falar-se aqui de estatuto ou «estado» legal não autoriza qualquer aproximação com a figura das relações especiais de poder. Em primeiro lugar, não se trata de um grupo de pessoas destacadas da colectividade dos cidadãos para efeito de sujeição a um regime especial: beneficiários do SNS são todos os cidadãos portugueses, todos os cidadãos nacionais de Estados membros da União Europeia nos termos das normas comunitárias aplicáveis e ainda outros. Por outro lado, não seria correcto falar-se em regime «de deveres agravados» em face de um complexo de normas que têm como núcleo caracterizador o reconhecimento de direitos a prestações como modo de concretização de um direito social fundamental.

Em suma, o estatuto não envolve aqui qualquer ideia de titularidade circunscrita no seio dos cidadãos. Trata-se antes da inclusão no estatuto de cidadania portuguesa (e nos estatutos de certos estrangeiros e apátridas em Portugal) de um regime de fruição do direito à protecção da saúde constitucionalmente reconhecido.

${ }^{60}$ Nos centros de saúde, existem registos de inscrição. Mas a inscrição nestes registos não constitui os inscritos no estatuto de beneficiários do SNS, que para eles resulta da Base XXV da Lei de Bases da Saúde. Destina-se tão só a formalizar a distribuição dos utentes pelos centros de saúde existentes.
} 
do serviço é meramente verificativo da existência de pressupostos que automaticamente fazem dela objecto de um direito e aquele acto apenas tem como efeito inovatório a inclusão do requerente no programa de efectivação dos cuidados, esse acto não é de admissão em sentido técnico-jurídico, por lhe faltar o efeito atributivo de uma nova situação jurídica. Ele limita-se a verificar a pré-existência de um direito aos cuidados e a fixar as coordenadas de tempo e distribuição de responsabilidades para efeito da respectiva satisfação ${ }^{61}$. Esta distinção não é desprovida de efeitos de regime, visto que, do carácter discricionário ou vinculado do poder exercido, depende a extensão do controlo jurisdicional admissível ${ }^{62}$.

Nos centros de saúde, fora das situações de urgência e do internamento no sector de internamento, o acto administrativo que inicia a relação de prestação é vinculado e reveste a forma de marcação de consulta. O utente tem direito a solicitar marcação de consulta para uma hora determinada. Quando seja possível, o atendimento terá lugar no próprio dia (Decreto-Lei n 157/99, de 10 de Maio, art. 9º $n^{0} 1$ ).

Os actos administrativos em causa marcam o início de uma situação específica de utilização de cuidados de saúde. É em face dos elementos dessa situação concreta que vão nascer direitos, interesses legalmente protegidos, deveres e sujeições imputáveis ao utente e que se individualizarão poderes, direitos e deveres da unidade de saúde em face daquele utente naquela situação.

\section{Desenvolvimento e extinção.}

29. Se, em grande número de vezes, a prestação de cuidados se cifrará numa simples consulta, em muitas outras, ela prolongar-se-á no tempo devido à necessidade de acompanhamento de um evento moroso só curável a prazo ou incurável. Nalgumas, poderá não ser fácil a destrinça entre várias relações de prestação de cuidados autónomos e sucessivos e uma relação continuada. Mas a distinção poderá ter de fazer-se, designadamente para efeito de aplicação do regime de prescrição do direito de indemnização por responsabilidade civil extracontratual das unidades de saúde e dos titulares dos seus órgãos e agentes por danos resultantes do exercício da função administrativa, nos termos combinados do artigo 5. ${ }^{\circ}$ do Regime de Responsabilidade Civil Extracontratual do Estado e Demais Entidades Públicas e do artigo 498..$^{\circ}$ do Código Civil.

Embora, como se viu já, a relação de prestação de cuidados seja «objectiva» e não contratual, as partes podem ir operando uma concretização ao longo do seu curso, feita de actos de solicitação ou consentimento do utente e de actos administrativos e materiais da unidade de saúde, envolvendo estes últimos discricionariedade técnica em sentido próprio, quando actos materiais, e, por vezes, discricionariedade jurídica, quando se trata de actos administrativos.

30. A extinção de cada relação jurídica de prestação de cuidados de saúde dá-se com o termo da prestação de um serviço de tratamento de um certo evento morboso.

${ }^{61}$ Cfr. GIANNINI, Diritto Amministrativo, II, 2. ${ }^{\text {a }}$ ed., Milão, 1988, pp. 1119 e 1120

${ }^{62}$ Sobre o carácter contenciosamente impugnável destes actos (ou melhor, do acto de recusa), ver: AUBY, Le Droit de la Santé, cit., p. 397; MOREAU/TRUCHET, Droit de la Santé Publique, cit., p. 138. 
No caso de consultas avulsas, isto é, que na altura de cada uma se estima não carecerem de continuidade, o serviço considera-se completado. Esgota-se por isso o objecto da relação.

As situações de internamento podem encontrar o seu termo por vários modos, cada um dos quais envolve regulação específica.

O modo mais frequente é o de concessão de alta, que tem natureza de acto administrativo. Mas esta não extingue e apenas modifica a relação se a alta dever ser seguida de consultas externas.

Dado que o utente tem o direito de decidir recusar a prestação de cuidados que lhe é proposta, pode abandonar por sua iniciativa o estabelecimento hospitalar em que se encontra internado. Deverá nesse caso assinar uma atestação de que foi informado sobre os riscos que tal decisão comporta. Esta liberdade não lhe assiste quando o internamento seja compulsivo ${ }^{63}$.

Se o utente recusa os tratamentos que lhe são propostos, deverá também ser posto fim ao internamento, devido à sua inutilidade, a menos que aquele careça de cuidados urgentes ${ }^{64}$.

Também a morte do utente põe termo à relação de prestação de cuidados. Este evento, quando produzido no decurso de um internamento, está regulado por um acervo de regras jurídicas em cujo quadro se gera uma relação jurídico-administrativa entre a unidade de saúde e os familiares, que têm direito a ser informados e ao cumprimento de certas formalidades quanto aos ritos funerários imediatos. O desenvolvimento da tecnologia de reanimação levanta problemas de crescente complexidade quanto ao emprego de meios de prolongamento artificial da vida em que a relação pode também ter de travar-se a partir de certo momento com os familiares ${ }^{65} 66$.

${ }^{63}$ Cfr. AUBY, Le Droit de la Santé, cit., p. 402, MOREAU/TRUCHET, Droit de la Santé Publique, cit., p. 140. Sobre a inexistência de um princípio geral de renunciabilidade das prestações objecto de direitos sociais, ver ÖHLINGER, Rechtsverhältnisse in der Leistungsverwaltung, cit., p. 196.

${ }^{64}$ Cfr. AUBY, idem, p. 406.

${ }^{65}$ Cfr. BRODY, Biomedical Technology and Human Rights, cit., pp. 187-203.

${ }^{66}$ Em rigor, deveria seguir-se ainda uma parte sobre «garantias». Mas o exame das especificidades que surgem quando se pretende aplicar o quadro geral de meios de tutela do administrado à relação jurídico-pública de prestação de cuidados de saúde requer um estudo autónomo. 